\title{
Saints, Sacred Trees, and Snakes: Popular Religion, Hierotopy, Byzantine Culture, and Insularity in Cyprus during the Long Middle Ages
}

\author{
Chrysovalantis Kyriacou
}

check for updates

Citation: Kyriacou, Chrysovalantis. 2021. Saints, Sacred Trees, and Snakes

Popular Religion, Hierotopy,

Byzantine Culture, and Insularity in Cyprus during the Long Middle Ages Religions 12: 738. https://doi.org/ $10.3390 /$ rel12090738

Academic Editors: Giorgos

Papantoniou, Athanasios K. Vionis and Christine E. Morris

Received: 3 August 2021

Accepted: 7 September 2021

Published: 9 September 2021

Publisher's Note: MDPI stays neutral with regard to jurisdictional claims in published maps and institutional affiliations.

Copyright: (C) 2021 by the author. Licensee MDPI, Basel, Switzerland. This article is an open access article distributed under the terms and conditions of the Creative Commons Attribution (CC BY) license (https:/ / creativecommons.org/licenses/by/ $4.0 /)$.
Bank of Cyprus Cultural Foundation, Nicosia 1515, Cyprus; chrysovalantis.kyriacou@hotmail.com

\begin{abstract}
The holiness of sacred spaces is expressed through the creative synthesis and performance of different symbolic or iconic elements. This article concentrates on the medieval church of Ayios Iakovos in Nicosia, Cyprus. Dedicated to Saint James the Persian, the church became, by the 1600s, a shared shrine for Christians of different denominations (Orthodox, Maronites, and Latins) and Muslims. The aim of this article is to investigate in an interdisciplinary way the formation, adaptation, and negotiation of insular religious identities in relation to Ayios Iakovos' hierotopy, official and popular religious practices, and the appropriation of Byzantine culture. The components in the creation of this sacred space reflect long-term contact between Cyprus and Greater Syria, constructing an inclusive religious environment with its own insular characteristics. It will be argued that these characteristics were shaped by global, regional, and local developments, including trade, pilgrimage, war, and environmental changes. Being in dialogue with recent scholarship on mixed sacred sites, this case study stresses the importance of interconnectivity and mobility in the creation of shared places of worship. It also shows that phenomena of religious co-existence and syncretism do not always result in homogenisation but maintain distinct group identities.
\end{abstract}

Keywords: multi-confessionalism; popular religion; sacred trees; snakes; insularity; connectivity; hierotopy

\section{Introduction}

In the early 1900s, people told a curious story about the great cypress growing near the small church of Ayios Iakovos at Nicosia (see Figure 1). Magda Ohnefalsch-Richter, who journeyed around Cyprus between 1894 and 1912, was informed by the area's Orthodox inhabitants that the cypress "is regarded as the most ancient [tree] of the island". She was also amazed to learn that the tree "is guarded by a big snake that hides during the day and appears only at night". Although she attempted to see the serpent with her own eyes, she was unsuccessful. Men, women, and children from the neighbourhood reassured her that the story was true, and that the snake had been guarding the tree for years. "Does this not remind", wondered Ohnefalsch-Richter, "of the Biblical snake of the Tree of Knowledge in Paradise?" (Ohnefalsch-Richter [1913] 2006, p. 231).

\section{Aim and Structure}

Focusing on Ayios Iakovos as a remarkable case study of official and popular religion that encompasses ritual healing, this article approaches the multi-faith society of Cyprus in the "long Middle Ages", and especially in the seventeenth century, by adopting an interdisciplinary perspective informed by the historical and cultural examination of archaeological testimonies, literary sources, and ethnographic accounts. This article aims to reconstruct the processes of insular identity formation, negotiation, and adaptation behind the long-term role of Ayios Iakovos as a sacred space. It will be argued that various local, regional, and global developments shaped the site's unique physiognomy. Although the driving forces behind Ayios Iakovos' hierotopic creation are often obscure, the religious 
and cultural connectivities between Cyprus and Byzantium are instrumental in helping us unlock the complexities posed by the shrine.

The article begins with an archaeological description of Ayios Iakovos and a survey of related historical sources from Byzantine (ca. 300-1191) to Ottoman times (1570/1-1878), stressing its diachronic value as a religious centre for Cypriot Christians (Orthodox, Maronites, and Latins) and Muslims. This is followed by a discussion of official and popular religious practices (including ritual healing). The article closes by defining insularity through local, regional, and global processes associated with Ayios Iakovos, and showing the relevance of this case study for the examination of shared places of worship.

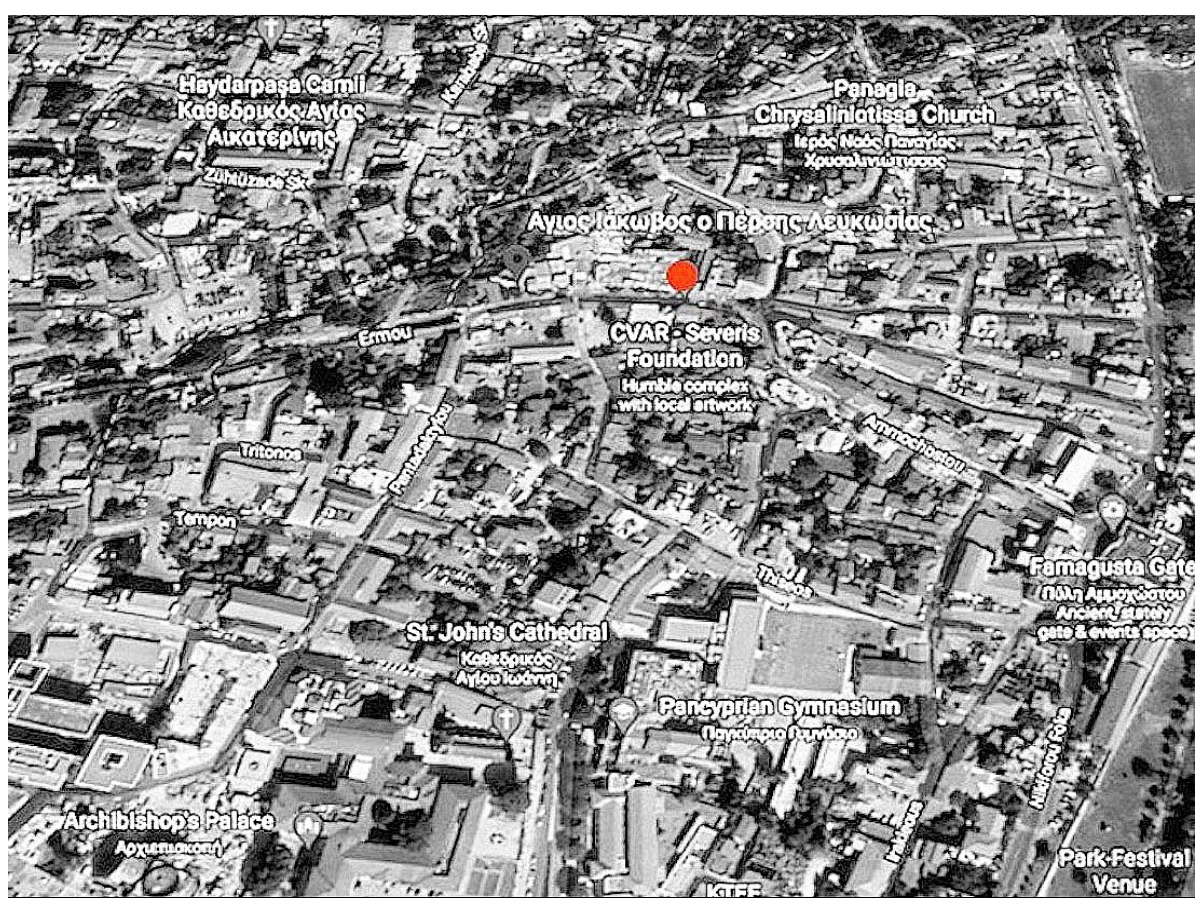

Figure 1. The location of Ayios Iakovos in modern-day Nicosia. 2021.

\section{Methodological Concepts \\ 3.1. Religious Groups}

Before moving on to the description and history of Ayios Iakovos, it is first important to define some key methodological concepts. The capitalised term "Orthodox" (which, at the time, was not restricted to any group) is used to describe Byzantine-rite Christians, who were mainly Greek-speaking and generally described themselves as Rhomaioi ("Romans") but were called by the Latins Greci (Graikoi) (Kaldellis 2019b). The Byzantine rite "is the liturgical system that developed in the Orthodox Patriarchate of Constantinople and was gradually adopted, in the Middle Ages, by the other Chalcedonian Orthodox Patriarchates of Alexandria, Antioch, and Jerusalem" (Taft 1992, p. 16). Although this should not be interpreted as implying complete ritual uniformity, it does suggest the existence of bonds of unity across the Byzantine world. "Byzantines" refers to subjects of the Byzantine Empire, while "Latins" refers to Latin-rite Christians in general. The choice to use "Byzantines" and "Byzantium", when referring to the medieval Roman Empire and its people, stresses the gradual dominance of Constantinople (Byzantion) "as the archetypal patria communis of the Rhomaioi", despite the existence of other identities, including local ones (Stouraitis 2017, p. 78; Chrysos 2016-2017; Eshel 2018, p. 202; Theodoropoulos 2021). In post-1300 Cyprus, we can trace the local identity of Kypriotis, shared by both Rhomaioi and Latin Cypriots (Grivaud 1995; Nicolaou-Konnari 2000-2001). However, the dominant identity among the island's Orthodox after the thirteenth century seems to have been the Rhomaic one (Perdikis 2004, p. 58; Kaplanis 2014; Kaplanis 2015), linking their self-perception to the religious and cultural legacies of Byzantium. 
The Maronites were an Arabic-speaking, Syriac Chalcedonian community, with strong Lebanese ties. Like Orthodox and Latin Christians, they were following the decrees of the Council of Chalcedon (451). An extensive discussion of the council and its aftermath is beyond the scope of this paper; in a nutshell, Chalcedon proclaimed Christ having two natures, being fully God and fully human (Borg 2004; Naaman 2011). In the seventh century, it appears that the Maronites adopted the Byzantine imperial formula of the one will of Christ (Monothelitism), promoted so as to reconcile Chalcedonian and non-Chalcedonian Christians. Monothelitism and its predecessor Monenergism (one activity in Christ) were initially accepted as doctrinally correct by most Churches but were gradually rejected as heretical by the majority of Christians in East and West (Salibi 1959, pp. 16, 44-46, 99-100, 137-39, 154; Hovorun 2003, pp. 335-49).

We come now to the identity of Cypriot Muslims in Ottoman times. From the fifteenth century onwards, there was "a growing concern within the Muslim communities in the 'lands of Rum' with defining and enforcing the boundaries of correct belief and practice", a process described as "confessionalisation" and "Sunnitisation" of the Ottoman Empire (Krstić 2021, pp. 7-8). Cyprus was one of those places where elements of Sufism (Bektahism and Alevism) seem to have found fertile soil (Jennings 1993, p. 160; Hatay 2015; Harmansah 2021). In the words of Mete Hatay, Bektashism expanded Islamic influence "by maintaining most of the pre-Islamic faith motifs and continuing many of the Christian-based traditions. The Bektashi faith was predominantly popular in the newly Islamicising societies" (Hatay 2015, p. 52).

\section{2. "Long Middle Ages"}

The longue durée exploration of Ayios Iakovos as a sacred place adopts Jacque Le Goff's perception of a "long Middle Ages", stretching from Late Antiquity (ca. 200-600) to the mid-1700s (Le Goff 2015). This study concentrates on the broader period between the tenth and seventeenth centuries, namely from the consolidation of Byzantine administrative and military presence in Cyprus (965) to the first century of Ottoman domination on the island (ca. 1570-ca. 1670). Since nearly all sources on Ayios Iakovos as a multi-faith site date from the 1600s, the seventeenth century will be our main point of discussion. Thus, from a chronological perspective, particular emphasis will be laid on what is usually defined in western European history as the "early modern period". This period is distinguished from the Middle Ages proper in that it is characterised by significant developments, including the New World discoveries, the invention of printing, the Renaissance, and confessionalisation. The impact of these developments is not to be underestimated; yet, it is important to transcend the rather artificial division between the (late) Middle Ages and (early) Modernity, so as to understand more comprehensively and with greater precision the continuities and discontinuities involved in Ayios Iakovos' hierotopy. Moreover, applying the term "medieval" for Byzantine and post-Byzantine religious culture enables scholars to move beyond the illusory view of Byzantium as "not being medieval" (Kaldellis 2019a, pp. 75-92), placing its rich and multi-faceted legacy within a broader medieval world in East and West (Patlagean 2014).

\subsection{Hierotopy}

Alexei Lidov defines "hierotopy" as "a type of creativity deeply rooted in human nature": humans create, spontaneously and/or deliberately, "a concrete milieu of [their] connection with the transcendental world" (Lidov 2009, p. 34). The recreation of biblical topoi in medieval East and West is an eloquent example of this creative mechanism of reproducing the sacred (Lidov 2009, p. 38). The natural world is also part of the hierotopic process. "Like a holy icon", writes Veronica Della Dora, "the earth and its variety of topoi" are to be understood as being "symbolic in the ancient, strong sense of the word, since 'symbol', sym-bolon, denotes coming together of two halves, the visible and the invisible" (Della Dora 2016, p. 8). As suggested by Ohnefalsch-Richter's account of the legendary cypress tree and its guardian snake near Ayios Iakovos, spatial experiences 
of the sacred often embrace practices and beliefs beyond those officially sanctioned by religious communities and their elites. In medieval Cyprus, as elsewhere in the eastern Mediterranean, aspects of pre-Christian religious culture were more or less "sanitised" and integrated into the Christian universe. The relationship between the subaltern traditions of the ancient pre-Christian world and the hegemonic tradition(s) of Christianity was largely characterised by constant negotiation, adjustment, and compromise (Kyriacou 2020b, pp. 117-56). Therefore, the distinction between official and popular religion, as well as between religion and magic, is not always clear. We will argue that it is exactly this blurring of pure categories and possibly the superimposing of different layers of hierotopic meaning that transformed Ayios Iakovos into a hospitable sacred space, allowing for the accommodation, but not homogenisation, of believers from different traditions.

\subsection{Ayios Iakovos and Shared Sacred Sites}

Shared sacred centres are a global phenomenon (Albera and Eade 2017). Maria Couroucli argues that "this kind of syncretic practice is more common in the Mediterranean world than elsewhere, in the home of all three major religions that have shaped the Western world", which could be partly explained by the fact that this is "one of the regions in which the humble and the illiterate have learned to accommodate themselves to more than one lord during a lifetime" (Couroucli 2014, p. 286). Dionigi Albera observes that "while mixed worship is still very much part of the religious landscape of the eastern Mediterranean, it is also by definition a relatively unstructured phenomenon". Albera suggests exploring mixed worship in its diverse contexts, which will help scholars "to arrive at a better understanding of these phenomena ... and to pay great attention to the specific features of each of them" (Albera 2012, p. 223).

Focusing on Ayios Iakovos as a case study of mixed worship in the eastern Mediterranean addresses these considerations. This article brings forth the endemic elements of Cypriot multi-faith society and contributes, through a discussion of the site's hierotopy, to reconstructing a unique "sacred landscape of imagination". The term has been employed by Ute Luig to describe the different ways sacred landscapes are perceived and interpreted in relation to ritual performance, power, and identity (Luig 2018, p. 12). Looking at Ayios Iakovos through the prism of insularity enables us to evaluate the dynamics of human mobility and interconnectivity (both physical, as well as religious and cultural) in the creation of a mixed centre of worship, echoing recent research on shared sacred spaces of the Mediterranean (Bowman 2012; Albera and Couroucli 2012; Barkan and Barkey 2014; Couroucli 2014, pp. 379-82). Moreover, Ayios Iakovos shows that shared sacred sites existed in earlier times and should not be considered as recent phenomena (cf. Turner and Turner 1978, pp. 36, 39).

Scholars have approached shared sacred sites as "hybrid" topoi (Albera 2012, pp. 228-32; Eade and Albera 2017, pp. 12-14). Although "there is no single, or correct, concept of hybridity", this article avoids using "hybridity" altogether, because of the term's colonial and pseudo-biological associations (Young 1995, p. 25). As noted by Couroucli, "sharing holy places does not imply the blurring of religious or cultural boundaries; it is part of the experience of living side-by-side in multicultural societies. Cosmopolitan societies ... are not melting pots, but places where identified social groups live in contiguity" (Couroucli 2014, p. 385). Writing about the Muslim communities of Latin Christendom, Brian A. Catlos argued that interest (self-interest and mutual interest) and convenience had been unifying factors in medieval mixed societies. Perhaps the concept of conveniencia, rather than convivencia (Catlos 2014, p. 524), should be applied in our case study as well. Interest and convenience are relevant to the centrality of Ayios Iakovos, a factor to be discussed later on that seems to have contributed to its spiritual magnetism. According to Robert M. Hayden, centrality in urban religioscapes indicates dominance (Hayden 2013, p. 327), which characterises the "competitive sharing" or "antagonistic tolerance" visible in mixed holy places (Hayden et al. 2016). This complex reality is mirrored in Ayios Iakovos, especially during the seventeenth century, when the church was shared by different groups 
of Christians and Muslims. As our case study will show, the co-existence of these groups in the same sacred space did not erase the boundaries separating them, which confirms Couroucli's statement that "sharing does not imply intimacy" (Couroucli 2014, p. 385).

\section{Ayios Iakovos: Archaeology and History}

\subsection{Architecture}

Today, Ayios Iakovos lies in the United Nations Buffer Zone, a victim of abandonment caused by the political peripeties of modern Cyprus. The church was heavily damaged by rainfall in February 2019; despite efforts for its restoration, it has remained in a ruinous state ever since (Domingo 2019). This is largely due to the fact that the Turkish military forces have placed the Buffer Zone area around Ayios Iakovos under their control (Creţu 2015), as well as due to the global pandemic emergency. As a result of the present political conditions in Cyprus, the architectural examination of Ayios Iakovos has been based exclusively on publications before 1974, especially Athena Tarsouli's drawing of the building in 1952 (Rizopoulou-Egoumenidou 2012, p. 292). Jacques Lacarrière's photograph from his 2003 publication on the Buffer Zone is also particularly useful (Lacarrière 2013, pp. 34-35).

From Tarsouli's drawing and Lacarrière's image, it seems that the church, dedicated to Saint James the Persian, had an aisleless nave, a semi-circular apse, and a cylindrical dome with narrow windows. Ayios Iakovos was restored by the powerful dragoman Hadjigeorgakis Kornersios (1779/80-1809) in 1793 (Lacarrière 2013, pp. 34-35; RizopoulouEgoumenidou 2012, pp. 291-92). In 1873, Archduke Louis Salvator of Austria described Ayios Iakovos as "a small building with four barrel vaults; upon these stands a square wall, carrying the cupola with eight little windows. The interior shows four pointed arches; the one on the back is lengthened out. The Ikonostasis [icon screen], carved of wood, bears the Russian eagle. The apse is a niche with pointed arches" (Salvator 1881, p. 33). The existence of Gothic pointed arches may point towards the thirteenth or fourteenth centuries (Papageorghiou 2010, p. 463). If this is indeed the case, we may wonder whether an earlier Byzantine church (if there had been one) was renovated around the mid-fourteenth century, employing masons familiar with the Byzantine and Gothic building traditions, as happened, for example, in the Orthodox cathedral of the Hodegetria at Nicosia (Papacostas 2005; Kyriacou 2018, pp. 88-90, 95-96, 116n54, 172n90; Patapiou 2019; Kaffenberger 2020). An icon of Saint James the Persian $(66 \times 29 \mathrm{~cm})$, probably transferred from Ayios Iakovos to Ayios Kassianos and now housed in the Byzantine Museum of Nicosia (see Figure 2), depicts the saint in military dress; the icon has been dated to the tenth century (Sophocleous 2014, pp. 145-47), but seems to belong to the thirteenth century (Eliades 2017, p. 95, Figure 50).

\subsection{Byzantine Syrian Parallels}

The existence of an Orthodox monastery dedicated to Saint James the Persian in Syria (Deir Mar Yac qub near Qara), whose eleventh-century decoration echoes Byzantine models and presents similarities to contemporary murals from Ayios Nikolaos tis Stegis at Kakopetria, Cyprus, could indicate direct or indirect contacts between Cyprus and Syria. This communication took place as part of a broader process of institutional, cultural and ecclesiastical Byzantinisation in the Levant from the mid-tenth to the twelfth centuries, namely during the re-establishment of Byzantine rule in Cyprus and Syria, and could support the hypothesis of the Byzantine founding of Ayios Iakovos at Nicosia (Snelders and Immerzeel 2012-2013, pp. 80-81; Galadza 2018).

A useful parallel would be that of Ayios Kassianos (Saint Cassian), near Ayios Iakovos. We know that, under Emperor Basil II (976-1025), Byzantine Antioch witnessed the rebuilding of the earlier church of al-Qusiyān, dedicated to Saint Cassian, which became the city's cathedral (Eger 2013, pp. 102-3). Ayios Kassianos in Nicosia is an eighteenth-century church with later additions and Gothic elements; its dedication suggests that the initial building may be dating back to Byzantine times (Coureas et al. 2012, p. 179; RizopoulouEgoumenidou 2012, pp. 284, 292; cf. Papageorghiou 1976, pp. 98-99). Our hypothesis 
seems to be supported by the fact that one of the island's Byzantine doukai based in Nicosia was Alexios Kassianos (1152-ca. 1174) (Papacostas 2012, p. 104). Future historical and archaeological research on Ayios Kassianos may reveal whether Alexios Kassianos should be considered as the founder or patron of the church. Other examples of Cypriot devotion to saints venerated in Byzantine Syria, during the eleventh and twelfth centuries, are those of Saint Symeon Stylites the Younger and Saint Phokas (Christodoulou 2010, p. 100; Caseau and Messis 2021).

Being the administrative centre of one of the most important Byzantine military bases in the eastern Mediterranean (Lounghis 2010, p. 30; Kyriacou 2020b, pp. 2-9), Nicosia reproduced the sacred topographies of Constantinople (Ayia Sophia and Ayios Georgios ton Manganon) (Papacostas 2005; Pilides 2012) and Antioch (e.g., Ayios Iakovos and Ayios Kassianos). Despite the lack of concrete archaeological evidence dating to the middle Byzantine period, the dedication of two nearby churches in Nicosia to saints venerated in Byzantine Syria is indicative of the strengthening of Byzantine presence in the Levant before and during the first Crusades, and its lasting impact on Cypriot religious culture.

\subsection{Historical Sources on Ayios Iakovos}

The history of Ayios Iakovos is interwoven with the multi-faith society of Cyprus in the "long Middle Ages". By the mid-fifteenth century, what had probably began as a Byzantinerite church passed under the Maronites and was known as Santo Jacobo di Maroniti (Richard 1981, pp. 90,119). Parenthetically, the sources mention another church dedicated to Saint James (perhaps not the Persian) in Nicosia, which was probably situated on the site of a later Ottoman mosque, the Sarayönü Camii. This church was Latin and should not be confused with Ayios Iakovos (Lusignan 1580, ff. 89r, 90v; Richard and Papadopoullos 1983, pp. 111, 192-93; Coureas et al. 2012, p. 276). Under the Maronites, Ayios Iakovos became the seat of the local Maronite bishop (Patapiou 2010). An anonymous Venetian report on the Christian communities of Cyprus, composed in the 1560s and preserved in codex Bank of Cyprus Cultural Foundation B-030, states that the Maronites of Nicosia possessed a certain monastery by the name of San Fosi, the income of which was used to support their bishop (Kyriacou 2019, pp. 74, 104, 150; Kyriacou 2020a, p. 72). Perhaps San Fosi is a scribal error made during the transcription of San Persi, "Saint Persian"; if so, San Fosi would be referring to Saint James the Persian (see Figure 2). The saint's Syriac/Arabic name,

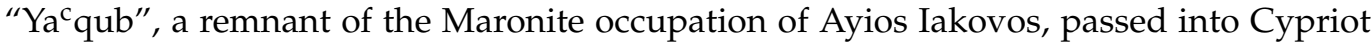
Greek, ultimately becoming "Akoufos" and associated, as a result of false etymology, with the miraculous healing of deafness by Saint James (Loukatos 1962).

In 1596, more than twenty years after the Ottoman conquest of Cyprus (1570-71), Girolamo Dandini, an Italian Jesuit on his way to the Maronite communities of Lebanon, visited Nicosia. The Maronites of Cyprus had been recognising papal authority since Frankish times (Schabel 2001, pp. 248-49); in 1445, their bishop, Elias of Byblos, made a proLatin confession of faith and his representative, Isaac of Minya, travelled to Rome, receiving the right to bless marriages between Latins and Maronites (Kyriacou 2018, p. 154). In the 1560s, the anonymous Latin author of codex B-030 accused Cypriot Maronites of being non-Chalcedonians (adhering to the belief that Christ has a single nature, the divine) and Monenergists (Christ has a single activity). The island's Maronite community was also said to be divided between those following the Maronite bishop in Nicosia and the followers of the Maronite patriarch in Lebanon (Kyriacou 2019, pp. 61-62, 74, 91-92, 104, 124, 150; Kyriacou 2020a, p. 72). This division was the result of a clash between the pro-Latin Cypriot Maronites and Patriarch Mikhail al-Ruzzi (1567), whom the former accused of departing from the Chalcedonian doctrine and pursuing a pro-Jacobite (non-Chalcedonian) theological line. Papal intervention eventually led to the pro-Roman declaration of Qanubin in 1580, affirming the Chalcedonian line; moreover, a Maronite college was established in Rome for receiving Maronite students. Thus, Dandini's mission to the East in 1596 aimed at ensuring that the Maronites remained truly united with the papacy in matters of faith (Harris 2012, p. 94; Kyriacou 2019, p. 149). According to Dandini, the Maronite church of 
Nicosia, most probably a reference to Ayios Iakovos, was in a poor state and in need of all kinds of liturgical equipment (Dandini [1675] 1685, p. 30).

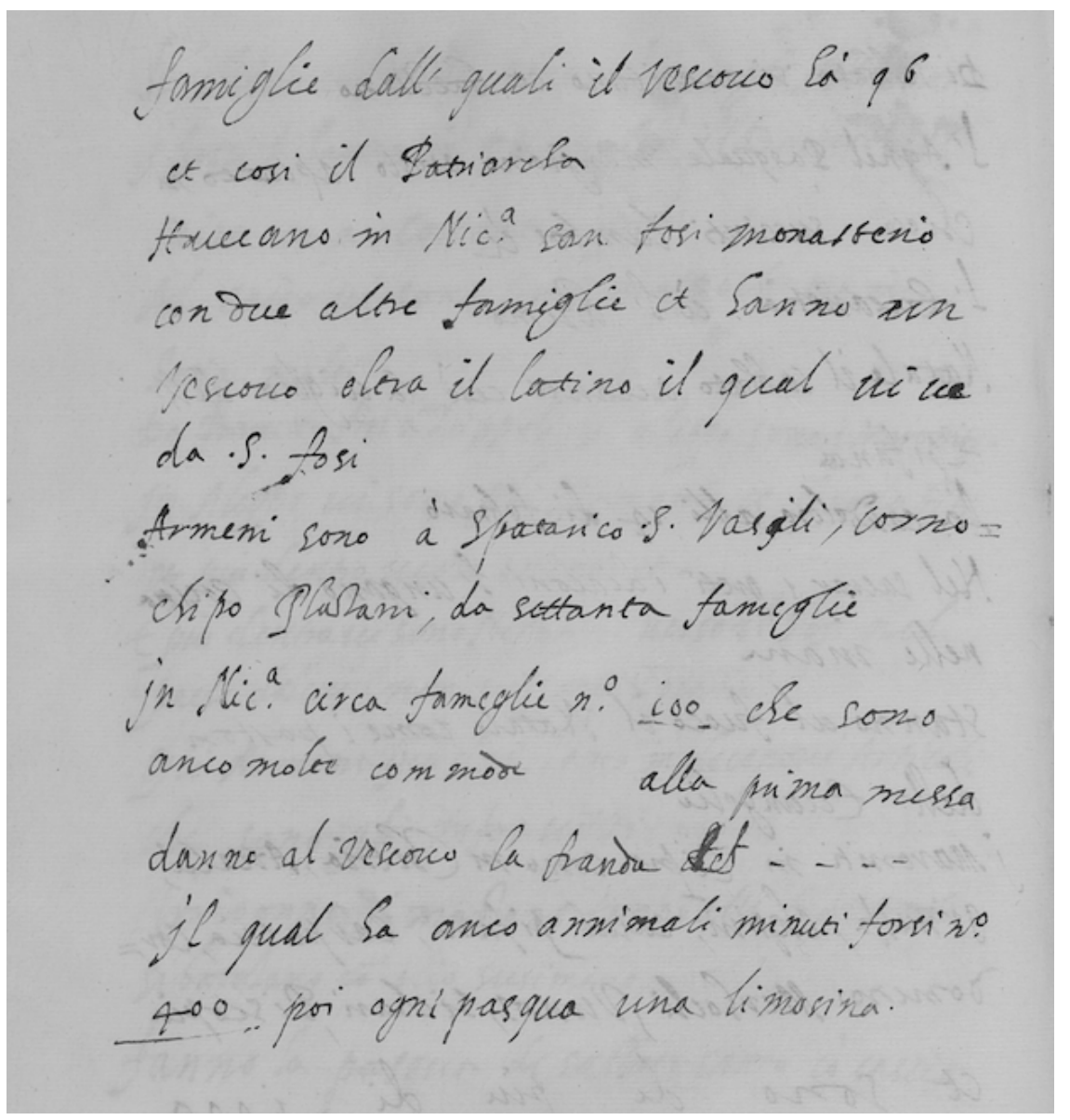

Figure 2. Codex Bank of Cyprus Cultural Foundation B-030, f. 37v, mentioning (in line 3) the Maronite monastery of San Fosi, which may be referring to Ayios Iakovos.

Almost a century after Dandini's visit, Michel Febvre (alias Justinien de Neuvy), a Capuchin established in Aleppo in the 1670s, provided additional information on the fate of Ayios Iakovos after the Ottoman conquest (Heyberger 2012, pp. 496-97). Ayios Iakovos, we read in Febvre, had been desecrated and used by a Janissary as a stable, until Saint James appeared in his dream, demanding that he restored the church. The Janissary ignored the warning, but the dreams continued and his camels died suddenly. The Janissary immediately abandoned the building, which was eventually bought by French Capuchin friars. Ayios Iakovos was restored and even the local Muslims visited the shrine, anointing their sick with sacred oil from Saint James' lamp. Writing at the beginning of the twentieth century, Frederick Hasluck noted that a similar story was told about the church of Saint James the Persian at Nisibis, which had been converted into a granary by the Muslims. Again, the saint appeared in the owner's dream, forcing him to abandon the church, which was eventually occupied by the Jacobites (non-Chalcedonian Syrians) (Febvre 1682, pp. 7-9; Hasluck 1929, pp. 42-43; Kitromilides 2009, pp. 105-6). At first sight, Febvre's account presents a rather different version of Ayios Iakovos' afterlife than the one suggested by Dandini, but the two versions need not be mutually exclusive: the Maronites might have continued to be using Ayios Iakovos as their church in 1596, when Dandini visited Nicosia; at some point later, the church was taken over by a Janissary and was desecrated, but was recovered by the Capuchins, as related by Febvre.

Archival sources on the activity of Roman Catholic missionaries in the Levant provide additional information on the fate of Ayios Iakovos in the seventeenth century. The journey 
of three Capuchin friars-Pacifique de Provins, Pacifique de Paris, and Augustine de Pontoise-in Aleppo, Alexandretta, and Cyprus, resulted in the founding of two missionary bases on the island, in the port city of Larnaka and Nicosia (1627-1628). Upon their arrival in Cyprus, Pacifique de Provins is mentioned to have bought Ayios Iakovos, which had been turned into a stable by a Janissary (Seggiano 1962, pp. 110-11; Tsirpanlis 2006, pp. 270-71).

In 1629, Pietro Vespa, a Venetian Carmelite friar, was appointed Latin bishop of Paphos. This marked the institutional re-establishment of Roman Catholicism in Cyprus after the Ottoman conquest and the elimination of Latin ecclesiastical hierarchy (Tsirpanlis 2006, pp. 269-73). In a letter to the Propaganda Fide in 1638, Vespa claimed to have himself bought the church, wishing to make it his cathedral, but this was not accepted by everyone in the Latin community of Cyprus. Vespa stated in his letter that the Observant Franciscans wished to become the only Catholic missionaries in the Levant, for which reason they wanted their own church (Santa Croce), situated near the Paphos Gate, to function as a cathedral. Vespa insisted, arguing that Ayios Iakovos (San Giacomo) was a better option, since it was situated in the Latin quarter (doue stano li Latini), at the centre of Nicosia (nel mezzo della cità) (Tsirpanlis 1973, p. 67).

Throughout the seventeenth century, Ayios Iakovos was run by the Capuchins. In 1637, the friars seem to have founded a seminary for Maronite children (Seggiano 1962, p. 111; Tsirpanlis 1973, pp. 60, 211). In 1647, there was only one priest serving there (Tsirpanlis 1973, pp. 116, 118); in 1661, a missionary report pointed out that the building was old and in poor condition, but the Holy Eucharist continued to be administered, the church was decorated and had a street light (lampada publica) (Tsirpanlis 1973, pp. 166-67). In 1662, Giuseppe Maria de Bourges sent a report to the Propaganda Fide in Rome, containing a more detailed account of Ayios Iakovos' role as a religious centre. According to Bourges, the French Capuchins were celebrating Mass without any restrictions. Among their flock, there were also Greci, both men and women, who frequented the two Latin churches of Nicosia daily and with great devotion. In Ayios Iakovos, there was an old mural painting of Saint James the Persian, venerated by Greci and Turks of both sexes, who brought children suffering with hearing problems to be healed. Entering the church, related Bourges, one took a piece of cotton and soaked it into the holy oil of the lamp hanging in front of the altar. People anointed the ears of their sick, crossing themselves and saying a prayer to Saint James. As a result of the great number of miraculous healings, the Turks wished to pay the Capuchins, but the friars refused the money, saying that they lived on alms. The Turks, then, brought candles and oil to the church and, sometimes, bread for the friars. Bourges closed his account on Ayios Iakovos by remarking that the same devotion to Christian saints could be observed in other areas of Turkey, where the sick of the Muslims were miraculously healed by the grace of God (Tsirpanlis 1973, pp. 178-79; cf. Foulias 2020, p. 92).

It seems that we possess no substantial information concerning the church until 1793 (cf. Archimandrite [1788] 1902, p. 587), when Hadjigeorgakis Kornesios bought and restored Ayios Iakovos. The church once again passed to the Orthodox community (Rizopoulou-Egoumenidou 2012, p. 292). Sometime around 1858, Kallistratos, a Constantinopolitan hieromonk, came to Nicosia and was established in Ayios Iakovos. Kallistratos, once a monk at Mount Athos, and his disciples were instrumental in the revival of Orthodox monasticism in Cyprus (Kokkinoftas 2018, pp. 197-200).

Sadly, the political antagonisms and national conflicts of the second half of the twentieth century put an end to the diachronic role exercised by Ayios Iakovos as a religious magnet for the Orthodox, Maronites, Latins, and even Muslims of Cyprus. Abandonment and the wrath of nature have almost totally destroyed the church; like the old cypress and its guardian snake mentioned by Ohnefalsch-Richter, Ayios Iakovos is becoming more and more a faded memory, an almost-forgotten relic lost in the mist of times irrevocably passed. 


\section{Zooming in: Popular Religion and Hierotopy}

\subsection{Iconic Elements}

Having surveyed the architecture and history of Ayios Iakovos, it is now the moment to focus on the church as hieros topos, a sacred space consisting of different iconic elements. A spatial icon "is a category of icons which are not painted on wooden boards but are composed in one way or another out of spatial elements. It remains an icon in more or less customary sense-it is just implemented with unusual tools and materials" (Simsky 2020, p. 21). This concept is particularly useful for the study of Byzantine hierotopy: icons are merged with liturgy "in a unifying spatial space", each component functioning "as a point of contact between two worlds: Heaven and Earth". As noted by Andrew Simsky, this broader conceptual category of "icons" (including liturgical ritual, ecclesiastical architecture, art and music, and light dramaturgy) "are not merely the principal sensemaking elements of the sacred space, but rather the epitome of the general principle of iconicity that endows the entirety of the sacred space" (Simsky 2020, p. 16).

In the case of Ayios Iakovos, there are three main iconic elements deserving our attention: (a) Saint James the Persian; (b) the ancient tree; and (c) the guardian snake.

\subsection{Saint James the Persian}

We have seen that Saint James the Persian has been venerated diachronically by Orthodox, Maronite, and Latin Christians, as well as by Muslims. The inclusive nature of this devotion is embodied by the church itself, especially the mural painting and holy oil from the saint's lamp mentioned by Febvre and Bourges. Pilgrimage to Ayios Iakovos, closely associated with the healing ritual, was a synesthetic experience "both creating and engaging a narrative linking the body-individual and social group" with sacred space (Ashmore 2004, p. 261; cf. Vionis and Papantoniou 2019, p. 11). The crucial blending of senses must have been achieved through bodily movement in space: from the street into the church, perhaps through a courtyard, before the holy altar and the mural painting of Saint James. As noted by scholars, the physical experience of moving in space "has important implications for the maintenance of power relations", since, by controlling bodily movement, "it is possible to reproduce dominant perspectives on the world", shaping memory through spatiality and ritual performance (Vionis and Papantoniou 2019, p. 11). The architectural physiognomy of Ayios Iakovos combined Byzantine and Gothic elements; its decoration might have been enriched with both Maronite and Latin influences, creating a multi-layered holon that invited believers from different religious traditions to venerate the saint. This amalgamation of different religious and cultural identities produced, in the long term, shared religious practices, especially among "the simple". These were non-elite believers, belonging to different Christian communities but united in their shared devotion to Saint James; they were probably "mostly illiterate, and likely had little understanding of the theological complexities that split apart" the island's Christians (Tannous 2018, p. 3; cf. Grehan 2014, pp. 190-91). Acknowledging the reality of shared devotions (Olympios 2013) does not imply the disappearance of communal boundary building; indeed, rituals became visible and concrete identity markers that intentionally cultivated emotional responses and boundary maintenance on the believers' part (Kyriacou 2020a, pp. 23-25, 31, 36-38). However, Ayios Iakovos was the shrine of a saint belonging to the ancient, idealised past of the undivided Christian Church; for this reason, he could have been conveniently claimed by all Christians, even by some Muslims, in unofficial (or, at least, less officially sanctioned) ways that did not openly challenge official religion.

Saint James lived in Sasanid Persia around the early fifth century. A Christian apostate of Syriac origin, he pursued a high-ranking career in the Zoroastrian court of Yazbegerd I (399-420), but later returned to Christianity and received the crown of martyrdom under Bahram V (420-38) in 420-21 (Petra 2014, p. 131). Given the perennial enmity between Romans and Persians, the persecutions of Christians in Persia, and the role of Constantine I (306-37) as their alleged protector, we can understand why memories of Christian Persian martyrdom left their imprint on Byzantine ecclesiastical history and hagiography 
(Smith 2016). There are at least four recensions of the Byzantine Greek Passion of Saint James, translated from Syriac, highlighting the popularity of the saint in Byzantine times (Detoraki 2014, p. 74). What is emphasised in these recensions is the ritual mutilation of the saint by his persecutors, leading to a slow and horrible death (Devos 1953; Devos 1954). The Passion of Saint James was also popular in the West, reaching Latin, French, and English audiences of believers (Carruthers 2011). The saint's relics were transferred from Bet Lapat, the place of his martyrdom, to a Georgian monastery; during the persecutions following the Council of Chalcedon in 451, they were taken to Egypt by the non-Chalcedonian monk and theologian Peter the Iberian (d. 491). The saint's head was preserved in Nicomedia, until it was transferred by the monk Guillermus to the Cormery Abbey in France during the reign of Alexios I Komnenos (1081-1118); in ca. 1440, it was transferred once again, this time to Rome. In 1204, Bishop Nivelon de Chérisy found another head relic in Constantinople, which he believed to have belonged to the Persian saint. The bishop transferred the relic to Soissons; however, the Byzantines, under the Palaiologoi (1261-1453), continued to preserve a head relic of Saint James in the Pantokrator monastery at Constantinople. Moreover, the monastery of Saint John the Theologian at Patmos preserved a relic of Saint James the Persian in the early thirteenth century (Petra 2014, p. 136; Papacostas et al. 2007, p. 44). In Cyprus, a church dedicated to the saint, apart from the one in Nicosia, was founded some time before 1622 in the village of Choirokoitia (Hassiotis 2000, pp. 192-94). A village by the name of Ayios Iakovos, with a fifteenth-century (?) church, also exists in Trikomo, Karpasia (Smagas and Papagiannis 2017, pp. 258, 265; Chotzakoglou 2017, p. 292; Marangou 2019, pp. 128-35, 329). Although in the twentieth century the church was dedicated to Saint James, brother of the Lord, it might have been originally dedicated to Saint James the Persian; this hypothesis is strengthened by the existence of Gothic arches in both the Karpasia and Nicosia churches. During the consecration of the monastic church of Saint John Chrysostom at Koutzoubendes (1090), the monks deposited under the altar the relics of Saint Prokopios, Saint James the Persian, and Saint Marina (Papacostas et al. 2007, pp. 32, 44; Christodoulou 2009, pp. 47-48).

The latent connection between Saint James the Persian and his sacred cypress, seen by Ohnefalsch-Richter in the early twentieth century, points towards a Byzantine Orthodox liturgical and hagiographical reading (with a Syriac flavour) of Ayios Iakovos' hierotopic landscape. An eleventh-century kontakion (liturgical hymn) on Saint James describes his martyrdom, with the refrain metaphorically depicting the saint's mutilation as the pruning of a vineyard. The vegetal association of Saint James' death is stressed throughout the kontakion: the martyr's body parts fall on the ground like soft tree branches; Saint James is also praised as a beautiful and fruitful tree, whose fragrance is that of Paradise (Petra 2014, pp. 137-40). The same vegetal connection is to be found in the Syriac and Byzantine Greek versions of the Passion, with the Syriac text and Byzantine Greek recension $\alpha$ (tenth/eleventh century) even presenting the saint as a wounded, yet fragrant, cypress (Devos 1953, pp. 164-65, 177, 184-85, 187, 189, 191, 200-1, 208; Devos 1954, pp. 236-37, 244, 246, 255-56; Franco 2009, pp. 99-100, 107). Keeping in mind that Saint James' Persian community of Christians was, in fact, a branch of Syriac Christianity, "whose centre of gravity lay outside the Roman Empire and in the Persian (Sasanid) Empire to the east" (Brock 1987, p. xiii), we should interpret the tree imagery surrounding the martyr within a Syriac theological context, elements of which passed into the Byzantine tradition. For Saint Ephrem the Syrian (d. 373), "Christ himself is the fruit of [the] Tree of Life, who gives himself to be 'plucked daily' (i.e., in Communion) by the baptized: it is this fruit which confers divine life, providing humanity with the possibility, once again, of attaining that perfect state which had been intended for Adam and Eve" (Brock 1987). The Syriac tree typology sheds light on the tree imagery in the Byzantine liturgical and hagiographical texts on Saint James the Persian, explaining the existence of an ancient cypress near Ayios Iakovos. 


\subsection{Sacred Trees}

Dendrolatry was practised in Cyprus, as elsewhere in the eastern Mediterranean, from prehistory (Lightbody 2011; Flourentzos 2001; Goodison 2016; Tully 2018). One of the best-known examples of tree worship in ancient Cyprus was that of "Woodland Apollo", Apollo Hylates, worshipped at Kourion and Paphos, among other areas (Scranton 1967; Soren 1987; Mlynarczyk 1980; Papantoniou 2012, pp. 89, 97, 112, 137, 139, 148, 157, 226, 227, 231-32, 240-41, 343-44; Mavrojannis 2015; Hunt 2016, p. 243n39; Papantoniou 2016, pp. 78, 97). It is unclear whether the memory of this pagan cult was still visible during the Byzantine fifth century, when the apocryphal Acts of Saint Barnabas, set in the first century, described pagan rituals taking place near the sanctuary of Apollo (Rigsby 1996, pp. 257-60; Young 2005). Customarily, trees near Orthodox churches played an important role in healing rituals; pre-modern Cypriots used to hang clothes or rags on the branches, expecting that God or the venerated saint would miraculously intervene in support of the believer, through the "magical" transfer of the disease from humans to trees. This has been described as a form of "sympathetic magic" (Ionas 2013, pp. 27-32, 191-92, 212-17), especially in its contagious dimension: "things which have once been conjoined must remain ever afterwards, even when relation that whatever is done to the one must silently affect the other" (Frazer 1922, p. 174).

In Bilād al-Shām, Greater Syria, trees were iconic elements of sacred landscapes for centuries. In the biblical world, Asherah, the divine consort of Yahweh suppressed by the Deuteronomistic reform (seventh-sixth centuries B.C.), had sacred trees or wooden poles as her cultic objects (Dever 2005). Holy and eminent figures of the three monotheistic religions inherited the use of sacred trees, attracting believers of different traditions. Abraham's Oak at Mamre, near Hebron, was a magnet for pagans (in Late Antiquity), Jews, Christians, Muslims, and Druze (Lissovsky 2012, pp. 68, 70; Heyden 2020). In 1210, Rabbi Shemuel ben Shimson saw a tree over the tomb of Yonatan ben Uziel in Ammuqa, visited by Muslims, who brought oil and lit candles to honour the sage. In 1523, Rabbi Moshe Basola saw an old tree over the tomb of Rabbi Halafta, another Jewish sage, at Kefar Hanania (Lissovsky 2012, p. 75). ${ }^{\mathrm{c}} \mathrm{Abd}$ al-Ghani al-Nabulsi (1643-1731), one of the most significant Sufi scholars of the Ottoman period, sought shade and prayed with his companions under the great oak tree at $\mathrm{Ya}^{\mathrm{c}}$ qub al-Mansuri's shrine on Mount Lebanon. Jean de la Roque, who visited the Levant in 1689, relates that the Maronites celebrated the liturgy under the tall Lebanese cedars. When a sacred carob tree on the Mount of Olives at Jerusalem was nearly uprooted by a storm in 1690, a mastaba platform was constructed by local devotees in order to keep it alive (Grehan 2014, pp. 134-36).

It becomes clear that sacred trees were diachronically considered to be the meeting place between the human world and the divine, as well as symbols of life and fertility. For Harold W. Turner, "this place where other realms are meet is also indicated by various forms representing a link or connection between the human and transhuman spheres, and usually set in a vertical dimension as a ladder, poles and pillars, trees and hills" (Turner 1979, p. 24). According to Nurit Lissovsky, "the Mediterranean landscape was for many years subjected to burning, felling and grazing, which suppressed natural growth, so that the sacred tree became a landmark in the local landscape, as well as a store of seeds that could rehabilitate the vegetation of the region" (Lissovsky 2012, p. 76). In polytheistic communities, sacred trees over or near burial sites highlight the connection between dendrolatry and ancestor worship; in contrast, in monotheistic communities, sacred trees over or near burial sites do not imply ancestor worship (Dafni 2007a, p. 11). Another difference between polytheistic and monotheistic forms of tree worship/devotion is that in monotheistic communities the object of devotion is a single tree, while in polytheistic communities the object of veneration is the forest. A third difference is that monotheistic rituals and ceremonies associated with sacred trees are not part of the official religion, whereas polytheistic rituals and ceremonies play an important role in the official religion of polytheistic communities (Dafni 2007b, pp. 11-12). Amots Dafni's examination of rituals, ceremonies, and customs related to tree worship/devotion in the modern Middle East includes "family gatherings, conducting 
a Sulkha ["quarrel settling"], the leaving of food, the leaving of objects to absorb divine blessings and leaving objects for charity"; the same scholar notes that "the performing of official religious ceremonies under sacred trees was never recorded in present-day Israel and is typical of the old Semitic religions" (Dafni 2007a, p. 12). Lissovsky explores the crucial question of whether sacred sites became sacred because of the trees, or whether trees became sacred because of the site, pointing out that "cult sites were often located near great trees that were seen from afar and serve as landmarks, rather than that trees were planted because of their proximity to a tomb" (Lissovsky 2012, p. 80). In the Holy Land, most sacred trees can be found in rural locations, rather than settled ones; in the latter case, they are perceived by their devotees as easily accessible sources of divine power in everyday life, bringing health, fortune, fertility, and a good crop (Lissovsky 2012, pp. 82-83).

Having surveyed the multiple aspects of arboreal worship/devotion in Cyprus and Greater Syria, we turn once again to the cypress near Ayios Iakovos. While it is impossible to know the tree's exact age, Ohnefalsch-Richter's statement concerning its oldness should not be disregarded as the product of folk imagination. The enormous Abarkuh cypress in Yazd, Iran, for example, is considered to be around 4000 years old (Farahmand and Karimi 2018). Today, more than 200 age-old trees are protected by the Department of Forests of the Republic of Cyprus; the Ayios Nikolaos at Kathikas cypress is more than 700 years old (Department of Forests, Ministry of Agriculture, Natural Resources and Environment, Republic of Cyprus 2012). Another Cypriot example would be that of the old cypress (age unknown), of 25m height (called by the locals "teparissos"), to be encountered near the medieval chapel of Panayia Tochniotissa at Mandres, not far from Ayios Iakovos in Karpasia (Marangou 2019, pp. 353-59). By the 1900s, the Ayios Iakovos (in Nicosia) cypress seems to have become a landmark for the church itself, providing an easily accessible source of divine power in the daily life of its devotees, both Christians and Muslims. Given the theological symbolism of the cypress and other trees/plants in Saint James' liturgical and hagiographical dossier, we may argue that the cypress in Ayios Iakovos was a visible, tangible, and concrete manifestation of the saint itself, a truly iconic element of his real presence in Nicosia.

\subsection{Snakes}

We come now to the third iconic component of Ayios Iakovos' hierotopy: the snake. The dragon's defeat by the god/hero is a basic aspect of the "chaos combat" theme (Chaoskampf) in Mesopotamian cosmogonic myths, probably influencing the Jewish religious tradition and the Jewish Christian and Byzantine Orthodox theological imagery (Tsumura 2005; Angel 2006; Oancea 2017; Kyriacou 2020b, pp. 139-41). The so-called "Serpent Column", once a votive of the Plataean victory at Delphi, was transferred to the Hippodrome of Constantinople, where it was invested with various symbolisms and talismanic, anti-snake powers in Byzantine and Ottoman times (Stephenson 2016). Dafni notes that, among the Muslims and Druze of the Holy Land, serpents are still considered to be the guardians of sacred trees (Dafni 2007b, pp. 6, 9). In the Greek island of Kephallonia and the Italian village of Cocullo in Abruzzi, snake festivals continue to take place within a Christian context (Håland 2011).

In Antiquity, Cyprus was known as "the snake land", Ophiousa or Ophiodea (OhnefalschRichter [1913] 2006, p. 226). Ovid in his Metamorphoses (X.229) mentions the "Ophiusian plains" of Venus (Ophiusiaque ara), which scholars consider as one of the island's many names (Miller 1916, pp. 80-81, 477). Hellenistic statuettes depicting snakes are probably related to the cult of the serpentine Agathos Daemon, which might have included healing practices (Papantoniou 2012, pp. 176, 228-29). The Cypriot Ophiogeneis, a family of "snake-born" serpent charmers, attracted, because of their healing powers, Pliny the Elder's attention in the first century A.D. (Ogden 2013, pp. 209, 211-12). The ancient Chaoskampf theme is reproduced in Cypriot heroic folk songs from medieval Cyprus, praising the deeds of Byzantine warrior heroes slaying dragons and other monsters, while draconic toponyms are popular throughout the island (Kyriacou 2020b, pp. 47, 40-43, 48, 59, 61, 77-78, 130-31, 
135-40, 158). In 1760, the Italian scholar and traveller Giovanni Mariti (1736-1806) met a family of Orthodox healers in "Tremitiou", who could heal the bites of snakes by touch (Mariti 1792, p. 23). Similarly, Magda Ohnefalsch-Richter mentions that her husband, Max Ohnefalsch-Richter (1850-1917), met in ca. 1878 an Orthodox priest in Varosia who belonged to a family of healers. The healer-priest was said to perform a special ritual, repeating magic words in Arabic and Greek that (supposedly) transformed the serpent's poison into water: "Serasin, Serache, Soan, Aisarahia, Aduna, Isparu, Erichidara. 'To farmaki sou osan to ydor'" ((Ohnefalsch-Richter [1913] 2006, pp. 226-27); cf. (Ionas 2013, pp. 250-51)). In Orthodox Cypriot folk culture, snakes function as phallic symbols associated with fertility, for which reason various kinds of "snake bread" are traditionally prepared for wedding ceremonies. In earlier times, snakes were thought to be the protective spirits of houses, or even the embodiment of saints, if found near chapels. People believed that the dangerous viper, also known as "koufi" (perhaps from the Arabic "kufi") (Gonzalez 1991, p. 699), had a magic stone under her tongue (Ionas 2013, pp. 21-22, 146-48). The idea that snakes are deaf goes back to Antiquity (Kitto 1840, p. 154; Sakellarios 1868, p. 349) and is repeated by Mariti, who calls the viper "deaf snake" (Mariti 1792, p. 23). Although hard to prove, we may assume that the acoustic similarity between "kufi/koufi" (in Arabic and Cypriot Greek respectively) and "Akoufos", the Cypriot Greek name for Saint James the Persian, could have created the impression that the saint was also a protector against snakes and their venomous bite.

\section{5. "Snake Land"}

By the late fifteenth century, the ancient image of Cyprus as "snake land" seems to have assumed greater importance. This was no mere return to classical literary topoi, but the moment of creation of a new tradition, centred around the monasteries of Stavrovouni ("Mount of the Cross") on Mount Olympos and Ayios Nikolaos (dedicated to Saint Nicholas of Myra) on the Akroteri Peninsula. The founding of both monasteries was dated to the fourth century, when Saint Helen, the mother of Saint Constantine (Constantine I) and discoverer of the True Cross in Jerusalem, visited Cyprus. Leontios Makhairas, writing sometime during the first half of the fifteenth century, follows a twelfth-century Byzantine hagiographical source (Papadopoullos 1952) in describing Saint Helen's journey to Cyprus. Helen is said to have joined together pieces of wood from the True Cross and the crosses of the two thieves, creating new cross relics suitable for distribution. When the empress visited Cyprus, the island was troubled by a severe drought. One of Helen's cross relics suddenly disappeared, only to miraculously re-appear on "Mount Olympia", where the saint eventually established Stavrovouni, a monastery dedicated to the Holy Cross and preserving a cross relic. According to Makhairas, the founding of Stavrovouni brought rain and salvation to the people of Cyprus (Pieris and Nicolaou-Konnari 2003, pp. 67-69). Systematic archaeological examination on the site may confirm the tradition of the fourthcentury founding of Stavrovouni, whose Byzantine origins are, nevertheless, indisputable (Menardos [1970] 2001, p. 321; Metcalf 2009, pp. 389-90). Although neither Makhairas nor his Byzantine source mention snakes, their narratives depict Cyprus as a droughtstricken and lifeless island. As noted by a recent herpetological study on the Cypriot bluntnose viper, "water bodies are critical for sustaining both wildlife and human civilization [and] have been facilitating contact between people and reptiles for millenia" (Jestrzemski and Kuzyakova 2018, p. 2). Thus, the limitation of water resources during periods of drought could have made snakes more visible to humans, forging a connection between the legendary drought in Saint Helen's time and the "snake land" image of Cyprus. The tragic reality of water drainage gradually became embedded to the very representation of Cyprus as an island, inevitably transforming local perceptions and practices of hierotopy.

In 1453, Peter Rot, a pilgrim from Basel, passed from the Akroteri Peninsula, mentioning that the Orthodox monks of Ayios Nikolaos kept many cats, which they employed to exterminate the snakes inhabiting the area. The number of cats appears to have increased in the following decades, reaching 600 by 1470, when the last Lusignan king of Cyprus, 
James II (1463-73), supported the care of the monastery's cats with an annual income and veterinary services (Nicolaou-Konnari and Schabel 2015, pp. 318-19).

Snakes continued to command the interest of Cypriot and non-Cypriot Christians well after the Ottoman conquest of Cyprus. In 1580, Estienne de Lusignan, a native of Cyprus, noted that Akroteri was full of snakes and left a description of the ferocious Cypriot "Cuffi"; he also pointed out, probably repeating what the locals had told him, that Ayios Nikolaos had been founded by Kalokairos, the Byzantine duke of Cyprus, after the return of Saint Helen in Constantinople. According to Lusignan, the monks of Ayios Nikolaos had been armed with an army of cats since early Byzantine times, so as to kill the peninsula's dangerous snakes (Lusignan 1580, ff. 18r-19v). Although archaeological evidence concerning the early founding of the monastery is scarce, the argument in support of its Byzantine origins is generally accepted by scholars (Papacostas 2015, pp. 167-68; Olympios 2015, pp. 423-24). In 1596, Girolamo Dandini reported the existence of a great number of cats nourished by the Orthodox monks of Akroteri (Dandini [1675] 1685, p. 34). A few years earlier, in 1589, Jacques de Villamont passed from the monastery and described the snakes as very long and thick. At first, he did not believe the story of the snakecatching cats, but others reassured him that this was indeed the case. The monastery, we are told, was deserted, although the peninsula continued to be known as "Cat Cape" (Villamont [1596] 1609, p. 182). In 1788, the first modern Orthodox historian of Cyprus, Archimandrite Kyprianos, spoke of the terrible Cypriot viper. Kyprianos quoted Martin Crusius' (d. 1607) description, based on the account of the Cypriot Stamatios Donatos, of a serpentine monster living on Mount Olympos. The last pages of Kyprianos' historical treatise on Cyprus are dedicated to the treatment of snakebites, interestingly including the healing practices of Native Americans from Virginia (Archimandrite [1788] 1902, pp. 7, 591-94).

\subsection{Relationships of Iconic Elements}

Late medieval narratives on the founding of Stavrovouni and Ayios Nikolaos in Akroteri present the basic elements creatively combined in the hierotopic landscape of Ayios Iakovos in Nicosia. The historical Helen, mother of Constantine I and later saintly empress, was transformed by Orthodox Cypriot folk imagery, probably influenced by the pre-Christian cult of the Cypriot Goddess, into a divine female figure associated with rain, fertility, and agrarian regeneration (Menardos [1970] 2001, pp. 315-40; Psychogiou 2008, pp. 89-90; Kyriacou 2020b, p. 138).

The connection between Saint Helen, whose passage from Cyprus led to the founding of Stavrovouni and Ayios Nikolaos, and regeneration is stressed by the Byzantine Orthodox theological symbolism of the cross as the "tree of life", the "life-giving tree", and the "wooden spear" terrifying Hades. There is an explicit link between sacred tree/cross and snake, since in the Old Testament the cross is prefigured by the brazen snake raised by Moses on the pole to protect the Israelites from the snakes in the desert (Karagianni 2010, pp. $28,60,73,94)$.

The symbolic association between cross and tree was clear to the anonymous author of the Venetian report in Codex Bank of Cyprus Cultural Foundation B-030, who pointed out that sixteenth-century Orthodox Cypriots during Lent gathered under the liturgical cross in order to take a rest "as if under a shadowy and leafy tree" (Kyriacou 2019, pp. 52, 84; Kyriacou 2020a, p. 52). The Russian abbot Daniel, who visited Stavrovouni in the early twelfth century, specified that Saint Helen left a cross made of cypress wood there, which drove away the devil and healed illnesses (Menardos [1970] 2001, p. 321). This implies that the cypress was regarded by medieval Orthodox Cypriots with respect, strengthening the connection between sacred trees and the cross.

It would be useful to outline the relationship of the iconic elements discussed so far, having Ayios Iakovos as our main point of reference (see Tables 1-3). Note that cats do not appear in Stavrovouni and Ayios Iakovos; snakes, on the other hand, appear in Ayios Nikolaos and Ayios Iakovos but not in Stavrovouni, while the cross/sacred tree 
appears only in Stavrovouni and Ayios Iakovos. As suggested earlier, it is likely that the transformation of snake symbolism from negative to positive in Ayios Iakovos was shaped by the false Cypriot Greek etymology of the saint's Syriac/Arabic name: "the one who heals deafness/drives away vipers/koufades" = Akoufos $>\mathrm{Ya}^{\mathrm{C}} \mathrm{qub}$.

Table 1. Relationship of Iconic Elements at Stavrovouni.

\begin{tabular}{ccc}
\hline Saint Helen & Cross & Drought \\
\hline Founder of the monastery & Tree of Life & Evil \\
\hline
\end{tabular}

Table 2. Relationship of Iconic Elements at Ayios Nikolaos in Akroteri.

\begin{tabular}{ccc}
\hline Saint Helen/Nicholas & Cats & Snakes \\
\hline Divine protectors/patrons of the monastery & Protectors & Evil \\
\hline
\end{tabular}

Table 3. Relationship of Iconic Elements at Ayios Iakovos.

\begin{tabular}{ccc}
\hline Saint James the Persian & Cypress & Snake \\
\hline Martyr/holy healer & Sacred Tree & Guardian of the sacred tree \\
\hline
\end{tabular}

Popular devotion to Saint James the Persian, not necessarily in conflict with official religion, appropriated and creatively integrated, consciously or unconsciously, the three iconic elements appearing separately in the cases of Stavrovouni (Saint Helen and the cross/tree of life versus drought) and Ayios Nikolaos (Saint Helen/Saint Nicholas and the cats versus snakes). Unfortunately, we cannot know when exactly this creative integration took place, or how the various Christian and Muslim groups attracted by Saint James' shrine interpreted its hierotopy, producing ritual responses related to the sacred cypress and the snake. What we do know is that the hierotopic landscape of Ayios Iakovos was not created in a historical vacuum but reflects long-term processes and developments in Cypriot religious mentalities. Perhaps the way to understand why saints, sacred trees, and snakes became popular by the fifteenth century and as late as the 1900s is to address questions of insularity on a global, regional, and local level.

\section{Zooming out: Insularity and Its Broader Contexts}

\subsection{Insular Identities: Fragmentation and Connectivity}

Navigating the seascape of Mediterranean insularities is to map the complex and shifting dynamics of fragmentation and connectivity. Following the "New Thalassology" paradigm crafted by Peregrine Horden and Nicholas Purcell, we understand this narrative of "microecologies" as the child of Mediterranean tectonic processes and a "distinctive regime of communications made possible by the geography of the sea" (Horden and Purcell 2006, p. 733). Arthur Bernard Knapp argues that "island identities are fluid and situational, something islanders adopt or shed in tandem with what they wish to say about themselves, or the way they wish to be seen by others" (Knapp 2007, p. 51). As Christy Costantakopoulou states in her study on the Athenian Empire and the Aegean, a fuller examination of the interaction between humans and their landscape requires that we "differentiate between the world of the 'islands', a world dominated by interaction and connectivity, and the world of the 'island', an imaginary world of separation and seclusion" (Costantakopoulou 2007, p. 254). After all, there is a certain degree of conceptual flexibility in speaking about islands and insular identities: Fernand Braudel, for instance, saw the Syrian mainland, surrounded by sea and desert, as an island (Braudel [1949] 1990, p. 191).

Mobility, both human and in terms of circulating ideas and practices, is thus important in defining insularity. As nicely captured by Ottoman scholar Mustafā ${ }^{C} \bar{A} l \overline{~ o f ~ G a l l i p o l i}$ (d. 1600), the green meadow filled with military tents can be compared to the great number 
of "ships on the green sea [hoisting] white sails" (Römer 2001, p. 240). Writing on the Greek islands under the Venetians and the Ottomans, Spyros I. Asdrachas observes that, despite the diachronic predominance of agrarian economy and its implied forms of social stability, the lives of islanders have been shaped in different ways, directly or indirectly, by the everyday realities of war, trade, emigration, and travelling. This generates contact zones, internal circuits, and broader networks of communication (Asdrachas 1988, pp. 235-44).

Above all, questions of insularity need to be addressed as a way of charting and analysing the endemic features of distinct maritime regions. In his recent exploration of insularity in the Ottoman world, Antonis Hadjikyriacou reminds his readers that "islands need to be studied 'on their own terms', rather than from the external vantage point of continental realms" and that "islands are microcosms that can provide special insights into larger processes, global or otherwise" (Hadjikyriacou 2017, p. x). The same scholar carefully notes that "the study of islands is not an end in itself", since the concept of insularity should be seen merely as a methodological tool that enables us "to acquire a different perspective on the spatial, temporal or conceptual context one may choose to focus on" (Hadjikyriacou 2017, p. xi).

\subsection{Trade, Pilgrimage, Mobility, and Sacred Landscapes}

The rise of the Mongol Empire in Inner Eurasia enhanced the thirteenth- and early fourteenth-century tendency towards commercial globalisation, since "by protecting transEurasian commerce, Mongol rulers encouraged travel and trade along the Silk Roads" (Christian 2018, p. 5). In the words of Faruk Tabak, "during the thirteenth and fourteenth centuries, the principal commercial nexus shifted from the southerly maritime circuit, which pitted Baghdad against Cairo for the privilege for serving as the hub of this commercial world, to the continental land routes, the termini of which were located on the shores of the Pontic Sea". However, around the middle of the fourteenth century, a major change took place: "the southerly maritime route regained favor after the Mongol empire began to weaken", facilitating the rise of Venice and its domination in the Levant (Tabak 2008, p. 301). The Venetian convoys (nude), accompanied by armed galleys, were now regularly travelling to Cyprus, Alexandria, and Beirut, transporting spices and silks, grain, and oil ((O'Connell 2017, p. 109); cf. (Arbel 2007)).

The movement of people was driven by religion, as well as profit. The Byzantine recovery of Syria in the mid-tenth century and the establishment of Crusader states in the Holy Land in the twelfth century upgraded Cyprus into a key pilgrimage station for Christian travellers. In this period, trade contacts with both the Crusader states and the Islamic world seem to have been regular. After the Muslim conquest of Acre in 1291, Famagusta became a major relay station for pilgrims and merchants sailing to/from Jaffa and Alexandria, although the port's significance began to decrease after its Genoese capture in 1373 (Wartburg and Violaris 2009; Jacoby 2016). In the sixteenth century (1530s-1570), Venetian trade contacts between the island and Bilād al-Shām/Egypt intensified; Saline (Larnaka) emerged, next to Famagusta, as another important port in the Levantine basin (Arbel 2004; Patapiou 2009; Arbel 2014; Kyriacou 2019, pp. 67, 96-97; Kyriacou 2020a, pp. 64-65). The centrality of Cyprus in regional trade, facilitated by the broader global context, left its imprint on the Levantine orientation of local places of worship. We have already argued that Syrian venerations (Saint James the Persian, Saint Cassian, Saint Phokas, and Saint Symeon Stylites the Younger) were transferred in Cyprus during the last phase of Byzantine hegemony in the eastern Mediterranean. Under the Lusignans and the Venetians, pilgrimage connections between the island and Saint Catherine's monastery on Mount Sinai gave rise to the Cypriot veneration of Saint Catherine, shared by both Orthodox and Latin Christians and centred around her alleged birth in Cyprus and "Constantinian blood" (Calvelli 2014). That religious devotion, interwoven with the itineraries of seamen and travellers, is eloquently reflected in the creation of ship graffiti in churches situated in or near the harbours of Larnaka and Famagusta, a practice that seems to have become more 
common after the sixteenth century (Demesticha et al. 2017; cf. Walsh 2006; Walsh 2007; Michael 2015).

Crossing the sea more often, thus, acted as a catalyst to the transformation of physical landscape into holy space (see Figure 3). As noted by Michele Bacci, "mariners tended to attribute holiness to those elements of landscape that announced difficult manoeuvres or special risks during the navigation". This led to the dedication of promontories, which required particular navigation skills to be sailed around, to holy figures and their marking by churches or monasteries (Bacci 2014, p. 11). In summer, ships approaching Cyprus from the west with the meltem winds filling their sails, and those coming from the east and struggling against these same winds needed both nautical skills and divine help to reach their destination safely (Casson 1950, p. 45; Arnaud 2005, pp. 208-10). Stavrovouni, Saint Helen's Mount of the Cross, was the main landmark for ships heading to or coming from Larnaka, its peak being visible even in cloudy weather (Menardos [1970] 2001, p. 328). It has been suggested that the association of Ayios Nikolaos in Akroteri with "cats", and therefore the emergence of the snake-killing legends going back to Saint Helen and the actual upkeeping of cats by the local Orthodox monks, was the result of false translation from Greek to Italian. According to this theory, medieval mariners and cartographers might have mistranslated the Greek word agathos, a plant name, or Agata, referring to Saint Agatha and perhaps implying the existence of the pre-Christian toponym Agathe ("Favourable"), which passed into Italian as Gatte, meaning "cats" (Koutelakis 2010). At any rate, the increasing significance of both Stavrovouni and Ayios Nikolaos by the fifteenth century coincides with the regional prominence of Cyprus as a key hub in the marine highways of the Levantine basin.

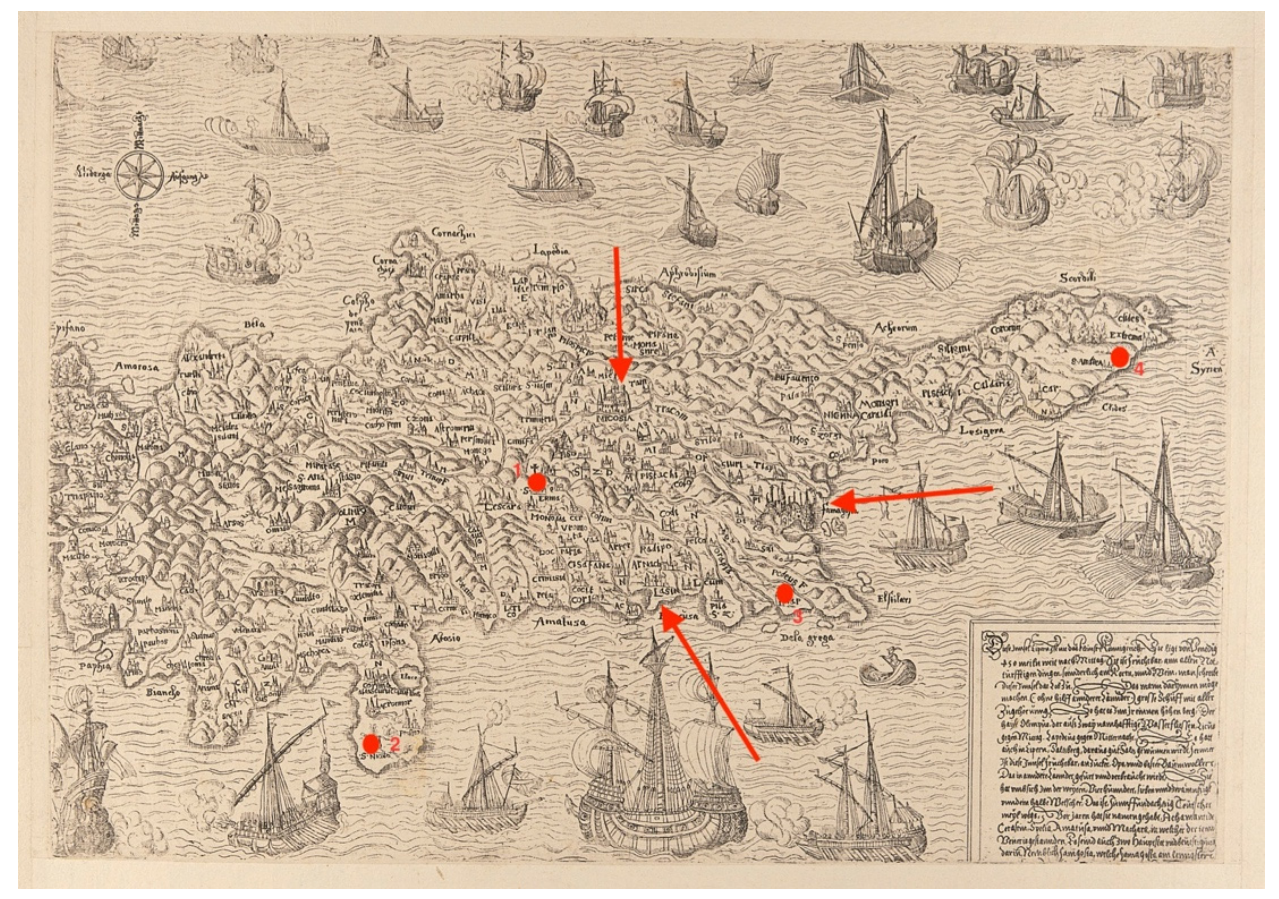

Figure 3. Map of Cyprus by Balthasar Jenichen, 1661. Bank of Cyprus Cultural Foundation, C-036. The arrows indicate the key economic centres of the "long Middle Ages": Nicosia at the centre, Larnaka in the south, and Famagusta in the east. Sacred landmarks for sailors, traders, and pilgrims are numbered: (1) Stavrovouni; (2) Ayios Nikolaos at Akroteri; (3) Ayia Napa; and (4) Apostolos Andreas.

During the course of the sixteenth century, the Ottomans managed, slowly but steadily, to bring most of the eastern Mediterranean under their control: Syria and Egypt were conquered in 1516-17, followed by Cyprus in 1570-1571 (Jennings 1993, p. 346). The change of rule and international developments (e.g., the use of the newly discovered Atlantic areas 
for the cultivation of Indian Ocean crops once largely cultivated in the Levant) affected the economic role of Cyprus, without however changing its Levantine orientation in the late sixteenth and for most of the seventeenth century (Tabak 2008, pp. 65, 302). The Ottomans renewed the Venetian ahidnâme (capitulation) in 1573, leading to the establishment of a Venetian consulate in Larnaka, acknowledged by scholars as one of the most important in the service of the Serenissima (Costantini 2009, pp. 151-78; Demilyürek 2010). According to Ronald C. Jennings, in the first decades after the Ottoman conquest, "merchants from Cyprus traveled regularly in Anatoli and Karaman provinces, to Aleppo (via Trabulus or Iskenderun), and to Egypt (at Iskenderiya, Dumyat, and particularly Cairo)" (Jennings 1993, p. 334). Christian and Muslim merchants also visited Cyprus and "the small size of the island enabled lots of people to utilize the bazaars and markets of Lefkoşa" (Jennings 1993, p. 342). Antonis Hadjikyriacou recently observed that "unlike the vast majority of Ottoman islands in the Aegean, Cyprus was large enough and had the geological and climatic conditions for a polycultural cash-crop oriented economy", involving brokers, manufacturers, and exporters (Hadjikyriacou 2016, p. 91). Colin Breen argues that "in the context of economic expansion, the network of khans was especially significant. These caravanserai or inns were a central feature of Ottoman urban development, built to facilitate and stimulate commercial trade and economic development". The Büyük Han (Great Inn) of Nicosia, near the Latin cathedral of Nicosia (turned into a mosque after 1570), is a good example of the economic and social role of these foundations under the Ottomans (Breen 2019 , p. 31). For the late sixteenth and greater part of the seventeenth century, when Ayios Iakovos mostly appears in written sources, Cyprus continued to serve pilgrims travelling to or returning from the Holy Land (Frazee 1983, p. 114). Despite the decline in numbers of Latin Christian pilgrims after 1570, as a result of the Ottoman conquest of Cyprus, pilgrimage tours from the west did take place and seventeenth-century pilgrimage literature flourished (Noonan 2007, pp. 184, 198, 201). The numbers of Orthodox Christian pilgrims (hajjis) seem to have been greater (Izmirlieva 2014); perhaps the earliest Greek account, in the form of a diary in verse, comes from the pen of Antonios Darkes, an Orthodox Cypriot priest of Latin descent, who visited the Holy Land in 1589/90 (Chrysochoides 2003, p. 108; Darkes [1645] 2017).

The ongoing human flow between the island and the Syrian mainland during the "long Middle Ages" could explain the existence of a sacred tree in Ayios Iakovos, given the diachronic popularity of sacred trees in Bilād al-Shām. The creative making of the sacred landscape in Ayios Iakovos incorporated elements (saint, tree, and snake) that were also characteristic of sacred landscapes in Greater Syria and were, thus, easily recognisable and acceptable by different religious and ethnic groups. The combination of these elements must have contributed to shaping Ayios Iakovos' hierotopic image as a religious "central place" for Christians and Muslims within the much bigger administrative and economic centre of Frankish, Venetian, and Ottoman Nicosia between the fifteenth and seventeenth centuries (Vionis and Papantoniou 2019). Alternatively, to use a term employed by Homi K. Bhabha, Ayios Iakovos was a "Third Space", the meeting ground of religious and cultural alterity, of hegemonic groups and subaltern ones, of symbols that could have been "appropriated, translated, rehistoricized and read anew" (Bhabha 1994, p. 37). The realities of everyday interaction miniaturised in Ayios Iakovos reflect the interconnection and reciprocity of members of Cypriot society, Muslim and Christian, engaged in economic transactions, intra-communal power struggles, patronage, and collaboration, regardless of religious and ethnic identities (Kyrris 1987; Hadjikyriacou 2016).

\subsection{Cypriot Experiences of the Early Ottoman Rule}

Scholars point out that the late sixteenth and early seventeenth centuries, when Cyprus came under the Ottomans, was a period of crisis for the eastern Mediterranean. The Ottoman Empire underwent various institutional transformations (largely caused by inflation and the Safavid/Habsburg wars) affecting taxation and administration (Pamuk 2001). In the case of Cyprus, we may observe a certain degree of decentralisation (Had- 
jikyriacou 2016, p. 83), in terms of local elite consolidation and communal representation (Hadjianastasis 2009; Hadjikyriacou 2019b), often leading to phenomena of corruption and oppression, which are traceable, for example, in the violent tax-collecting activities of the dragoman Markoullis (1668-1674) (Papadopoullos 1981, pp. 88-95; Hadjikyriacou 2016, pp. 85-86). Social misery was also the result of broader environmental anomalies, especially between 1580 and 1610: freezing winters and recurring drought were particularly felt in Anatolia and the southern Balkans between 1591 and 1596, when "Ottoman lands entered their longest drought in the past 600 years" (White 2011, pp. 136-37), causing "famine, social violence, population displacement, and infectious diseases" (Xoplaki et al. 2018, p. 373). Although the exact impact of these climate anomalies on Cyprus requires systematic examination, various studies (based mostly on literary evidence) suggest that the living conditions of the Cypriot peasantry in ca. 1600 were indeed exacerbated (Theocharides 1987; Jennings 1988; Jennings 1993, pp. 173-211; Grivaud 1998, pp. 258-59, 298-300, 312-13, 318-20, 323-26; White 2011, pp. 79-81, 90, 212; Lepida 2015; Hadjikyriacou 2019a; cf. Kolovos and Kotzageorgis 2019).

Given that the passage from Venetian to Ottoman rule had been sealed by conquest, with Nicosia alone providing nearly 14,000 Christian prisoners to the Ottomans (Costantini 2009, pp. 66-67), it is perhaps no coincidence that the seventeenth century witnessed a great number of anti-Ottoman revolts and plots on the part of the Christian (especially Orthodox Christian) population of Cyprus (Hassiotis 2010). Anti-Muslim sentiments might have been strengthened by the Ottoman burning of the great cross of Stavrovouni by the Ottomans in 1570 (Menardos [1970] 2001, pp. 293, 327). In 1606, the suppression of a Christian uprising was accompanied by the forced Islamisation of Cypriot children, which was lamented over by Christodoulos, the Orthodox archbishop (1606-40) (Miklosich and Müller 1865, p. 269; Hassiotis 2010, pp. 167-69). Western Christian corsair activity in the Levantine basin seems to have strengthened Cypriot Christian expectations for liberation and return to more merciful, as they hoped, conditions of rule (Hassiotis [1972] 2003, p. 55; cf. Krantonelli [1991] 2014, pp. 318-19). The extent to which the harsh experiences of the early Ottoman period were visualised through the late medieval image of Cyprus the "snake land" - tormented by drought and unusually large snakes (see, e.g., Villamont's testimony in 1589), but saved by the power of the cross, the saintly emperors of Byzantium, and the serpent-catching cats of Akroteri-remains to be ascertained (Stylianou and Stylianou 1985, pp. 198, 200-205; Fumaroli 1995; Hassiotis 2000, pp. 174-179; Walter 2006, pp. 61, 88-89; Marchesano 2010; Drakopoulou 2013; Dandelet 2014, pp. 138-98; Bireley 2014, pp. 36, 86-87, 130, 165, 284, 310, 312; Triantaphyllopoulos 2015).

The concept of martyrdom, closely related to the cross and Saint James the Persian's cypress, was known to all Christian groups worshipping within the walls of Ayios Iakovos in Nicosia. For Orthodox, Maronite, and Latin Christians familiar with the hagiographical and liturgical texts on Saint James, the cypress was a symbol of the saint's heroic confession of Christian faith and self-sacrifice in the hands of his tyrannical persecutors. The flower of life blossomed out of Saint James' martyrdom: by the 1900s, when Ohnefalsch-Richter visited the shrine, the saint's power had even transformed the venomous snake threatening Cyprus into a guardian of his sacred tree. In the seventeenth century, both Christians and Muslims venerated Saint James as a healer; for some, at least, he might have been a symbol of resistance to oppression and a source of moral strength in their daily misery. Catholic missionaries in the 1600s often mentioned in their reports the existence of former Christians/Muslim apostates who had converted to Latin Christianity (rinegati/renegati); in 1638, eleven of them had been baptised in secret in Ayios Iakovos, while in 1641, the Muslim qadi of Paphos and Limassol was tortured to death in Selimiye Camii for having professed the superiority of Christianity over Islam ((Tsirpanlis 1973, pp. 67-68, 70; Tsirpanlis 2006, pp. 282-83); cf. (Jennings 1993, p. 137)). These reports could be considered as reliable evidence for the phenomenon of crypto-Christianity in Cyprus under the Ottomans, which is better documented in later centuries (Kokkinoftas 2019). This does not necessarily mean that all Muslims visiting Ayios Iakovos were crypto-Christians; some of them might have 
been non-Sunni (Bektashi and Alevi) Muslims, as those worshipping in the Christian shrine of Ayioi Saranta at Tymvou (Foulias 2005). We may assume that the Muslims visiting Ayios Iakovos were familiar with the growing of sacred trees in the tombs of Sufi masters (Ephrat 2021, p. 125).

Therefore, the different iconic threads weaving the hierotopic tapestry of Ayios Iakovos in the seventeenth century managed to bring closer a diversity of religious groups. Orthodox and Maronite Christians rediscovered in Ayios Iakovos the ancient traditions of Syriac and Byzantine Christianity on martyrdom; Latin Christian missionaries re-established in Cyprus revived the saint's veneration as a symbol of spiritual rebirth and covert resistance to the domination of Islam; Christian converts from Islam sought comfort and moral strength; it is also likely that non-Sunni Muslims found there an easily-recognisable sacred landscape, which could be shared by their own group (cf. Kamberidis 2013; Grierson 2014).

However, sharing the same place of worship in the 1600s did not erase religious differences and did not bring homogeneity: Christians remained Christians and Muslims remained Muslims. To this division one should add sporadic outbreaks of tension and long-term antagonisms within and between the island's Christian groups. The competition between Bishop Pietro Vespa and the Franciscans was mentioned earlier. The creation of the Latin bishopric of Paphos inspired negative reactions among the Maronites, who were already under pressure by the Orthodox hierarchy (Tsirpanlis 1973, pp. 29-32, 67; Skordi 2019, pp. 33-40, 59-60, 63-67). The Latin missionaries were sometimes critical of the Orthodox religious customs and practices (Tsirpanlis 1973, pp. 166, 190). Lastly, the Orthodox responded to the Latin infiltration in different ways. Some pursued a diplomatic line of pro-Catholic unionism for the sake of securing Western military help against the Ottomans; others were hostile to Catholicism, adopting a rather "pro-Calvinist" stance; a third group was openly anti-Latin, returning to Byzantine patristic sources and models of power, in order to refute the Latins theologically and stress their supremacy as Christian elite (Kyriacou 2021, pp. 24-32). This picture of confessional fragmentation resists any attempt to see Ayios Iakovos as a laboratory of a new hybrid identity shared by all Cypriot worshippers.

\section{Conclusions}

This article aimed to examine Ayios Iakovos as a case study of official and popular religion in the multi-faith society of Cyprus during the "long Middle Ages". Given that many of the connections drawn are separated by great spans of time, our attention concentrated mainly on Ayios Iakovos as a multi-faith centre in the 1600s. Future studies on Ayios Iakovos will certainly profit from the improvement of political conditions in Cyprus, which could provide opportunities for in situ archaeological research. Moreover, future research in Venetian, Ottoman, and pontifical archives may bring to light more information on Ayios Iakovos and its multi-faith function in the seventeenth century.

What follows is a summary of this article's conclusions:

(a) Ayios Iakovos as a multi-faith religious site. The historical exploration of the shrine has confirmed its role as a shared holy place and healing centre in the seventeenth century. The architectural survey has shown the existence of both Byzantine and Latin influences, suggesting syncretism and confessional co-existence. We have proposed that the origins of Saint James the Persian's veneration in Cyprus could be traced back in Byzantine times, especially during the Byzantine rule in Cyprus and Syria between the tenth and twelfth centuries.

(b) Details in the creative making of sacred landscape. There are three iconic elements in Ayios Iakovos' hierotopic landscape: saint, cypress, and snake. The Byzantine dossier of liturgical and hagiographical texts on Saint James the Persian indicates an arboreal symbolism (the saint as a cypress tree) with roots in Syriac theology. The analysis of the three iconic elements connects Cyprus to Greater Syria, creating a familiar hieros topos for worshippers from different groups and the practice of healing. Apparently, this occurred without drawing a sharp line between official and popular 
religion. There are also some Cypriot parallels (Stavrovouni and Ayios Nikolaos at Akroteri), suggesting that the creative blending of iconic elements in Ayios Iakovos should be seen as part of the widespread perception of Cyprus as "snake land" after the fifteenth century.

(c) Global, regional, and local developments. From ca. 1400 to ca. 1700, trade and pilgrimage mobility in the eastern Mediterranean were important for reasserting the significance of holy shrines in Cyprus, both in maritime areas and the mainland. The orientation of Cypriot economy and pilgrimage traffic was largely Levantine, which supports our earlier interpretation of hierotopic mobility from Greater Syria to Cyprus. At the same time, the bleak conditions of the early Ottoman rule, exacerbated by environmental anomalies, created a new dynamic for worshippers attracted to Saint James' church at Nicosia. Ayios Iakovos encapsulates these broader tendencies, witnessing the interactive relationship (but not homogenisation) of different religious groups, each of whom had its own beliefs, anxieties, and expectations. Ultimately, Ayios Iakovos, with its healing powers and sacred iconic elements, provided the common ground for Orthodox, Maronites, Latins, crypto-Christians, and Muslims to co-exist and worship within its sacred enclosure.

(d) Byzantine connectivities. In the 1600s, when Ayios Iakovos became a Latin cathedral under the shadow of the Ottomans, the spiritual message of Saint James' story (sacrificial victory over death) seems to have become more relevant for Cypriot Christian believers, regardless of confessional identity. This was partly due to the revived interest of Muslim-ruled Cypriot Christians in the concepts of persecution and martyrdom. The theological symbolism of Saint James became possible through the translation of texts on his martyrdom from Syriac into Byzantine Greek (and later into Latin and other languages), initially in the tenth/eleventh century. Likewise, the emergence of the saint's veneration in Cyprus seems to date around the period of Byzantine rule in the Levant. Although Ayios Iakovos changed hands throughout the centuries, the saint's memory remained associated with his passion, bearing witness to the religious and cultural connectivities between Cyprus and the Byzantine world, as well as to the inclusive power of Saint James as a spiritual symbol.

(e) Ayios Iakovos and other shared sacred sites. This case study, with its emphasis on interconnectivity and insularity, echoes the tendency of recent scholarship to examine shared sacred sites within a much broader nexus of exchanges and mobility. The hierotopic combination of the three iconic elements analysed here is crucial in understanding the distinctive physiognomy of Ayios Iakovos as an "imagined" (per Luig) hieros topos. Like other places of mixed worship, Ayios Iakovos should not be viewed as a "melting pot", but rather as the home of various groups, who maintained their own traditions and remained open to syncretism. What is rather atypical in the case of Ayios Iakovos, is the fact that the church is not a rural one. According to Albera, "mixed attendance ... tends to focus on very small rural shrines that are deep in the countryside and associated with rituals based on the farming calendar" (Albera 2012, p. 228). This could be probably the result of the long history of Ayios Iakovos changing hands as time went by. As suggested by seventeenth-century sources, the communities whose history remained associated with the site continued to be attracted by it, regardless of who possessed it. To remember Hayden, centrality indicates dominance and highlights the competitive co-existence of religious groups in mixed holy places. Clearly, this view is reflected in Vespa's aforementioned statement in 1638 that Ayios Iakovos should become the Latin cathedral, because of its centrality in the Latin quarter and the city of Nicosia. The success of Ayios Iakovos as a shared sacred centre might have been also related to what Albera describes as "devotional ambivalence" (Albera 2012, p. 230). Due to his Persian/Syrian origins and popularity in East and West, Saint James belonged to everyone and was venerated by everyone, even if the cultures, beliefs, and expectations of his devotees were not always the same. 
Funding: This article is part of the research project "Aspect of multiconfessionalism and human geography in early modern Cyprus, from the Venetians to the Ottomans-CyChrist" (RESTART 2016-20, DIDAKTOR, POST-DOC/0916/0060), co-funded by the European Regional Development Fund and the Republic of Cyprus, through the Cyprus Research and Innovation Foundation, and hosted by the Bank of Cyprus Cultural Foundation.

Institutional Review Board Statement: Not applicable.

Informed Consent Statement: Not applicable.

Data Availability Statement: Not applicable.

Acknowledgments: I would like to thank the editors and reviewers for their comments and suggestions. Many thanks also go to Ioanna Hadjicosti, Christodoulos Hadjichristodoulou, Charalambos Dendrinos, Laura Franco, Nasa Patapiou, and David Williams for their valuable help.

Conflicts of Interest: The author declares no conflict of interest. The funders had no role in the design of the study; in the collection, analyses, or interpretation of data; in the writing of the manuscript, or in the decision to publish the results.

\section{References}

Albera, Dionigi. 2012. Crossing the Frontiers between the Monotheistic Religions, an Anthropological Approach. In Sharing Sacred Spaces in the Mediterranean. Christians, Muslims, and Jews and Shrines and Sanctuaries. Edited by Dionigi Albera and Maria Couroucli. Bloomington and Indianapolis: Indiana University Press, pp. 219-44.

Albera, Dionigi, and Maria Couroucli, eds. 2012. Sharing Sacred Spaces in the Mediterranean. Christians, Muslims, and Jews and Shrines and Sanctuaries. Bloomington and Indianapolis: Indiana University Press.

Albera, Dionigi, and John Eade, eds. 2017. New Pathways in Pilgrimage Studies: Global Perspectives. New York and London: Routledge.

Angel, Andrew R. 2006. Chaos and the Son of Man. The Hebrew Chaoskampf Tradition in the Period 515 BCE to 200 CE. London and New York: Bloomsbury.

Arbel, Benjamin. 2004. The Last Decades of Venice's Trade with the Mamluks: Importations into Egypt and Syria. Mamluk Studies Review 8: 37-86.

Arbel, Benjamin. 2007. Venetian Letters (1354-1512) from the Archives of the Bank of Cyprus Cultural Foundation and Other Cypriot Collections. Nicosia: Bank of Cyprus Cultural Foundation.

Arbel, Benjamin. 2014. Maritime Trade in Famagusta during the Venetian Period (1474-1571). In "The Harbour of all this Sea and Realm": Crusader to Venetian Famagusta. Edited by Michael J. K. Walsh, Tamás Kiss and Nicholas Coureas. Budapest and New York: Central European University Press, pp. 91-103.

Arnaud, Pascale. 2005. Les Routes de la Navigation Antique: Itinéraires en Méditerranée et Mer Noire. Paris: Errance.

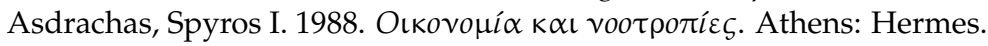

Ashmore, Wendy. 2004. Social Archaeologies of Landscape. In A Companion to Social Archaeology. Edited by Lynn Meskell and Robert W. Preucel. Malden and Oxford: Blackwell, pp. 255-71.

Bacci, Michele. 2014. On the Holy Topography of Sailors: An Introduction. In The Holy Portolano. The Sacred Geography of Navigation in the Middle Ages. Edited by Michele Bacci and Martin Rohde. Berlin, Munich and Boston: De Gruyter, pp. 7-16.

Barkan, Elazar, and Karen Barkey, eds. 2014. Choreographies of Shared Sacred Sites: Religion, Politics and Resolution. New York: Columbia University Press.

Bhabha, Homi K. 1994. The Location of Culture. London and New York: Routledge.

Bireley, Robert. 2014. Ferdinand II, Counter-Reformation Emperor, 1578-1637. New York: Cambridge University Press.

Borg, Alexander. 2004. A Comparative Glossary of Cypriot Maronite Arabic. Leiden and Boston: Brill.

Bowman, Glenn, ed. 2012. Sharing the Sacra. The Politics and Pragmatics of Inter-Communal Relations around Holy Places. New York and Oxford: Berhahn.

Braudel, Fernand. 1990. La Méditerranée et le Monde Méditerranéen à l'époque de Philippe II. Paris: Armand Colin, vol. 1. First published 1949.

Breen, Colin. 2019. The early Ottomanization of urban Cyprus. Post-Medieval Archaeology 53: 21-37. [CrossRef]

Brock, Sebastian. 1987. The Syriac Fathers on Prayer and the Spiritual Life. Kalamazoo: Cistercian Publications.

Calvelli, Lorenzo. 2014. Cypriot origins, Constantinian blood: The legend of the young Saint Catherine of Alexandria. In Identity/Identities in Late Medieval Cyprus. Edited by Tassos Papacostas and Guillaume Saint-Guillain. Nicosia: Cyprus Research Centre, pp. 361-90.

Carruthers, Leo. 2011. A Persian Martyr in a Middle English Vernacular Exemplum: The Case of St James Intercisus. Medieval Sermon Studies 55: 13-30. [CrossRef]

Caseau, Béatrice, and Charis Messis. 2021. Saint Syméon Stylite le Jeune et son héritage au XI ${ }^{\mathrm{e}}-\mathrm{XII}$ siècle. Bv $\zeta \alpha v \tau \imath v \alpha \dot{\alpha} \Sigma v \mu \mu \varepsilon \iota k \tau \alpha 31$ : 241-80.

Casson, Lionel. 1950. The Isis and her voyage. Transactions of the American Philological Association 81: 43-56. [CrossRef] 
Catlos, Brian A. 2014. Muslims of Medieval Latin Christendom, c. 1050-1614. Cambridge: Cambridge University Press.

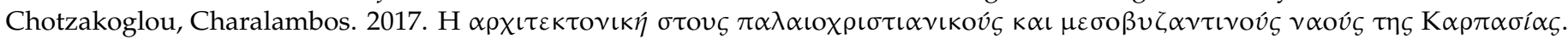

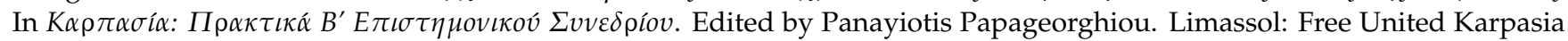
Association, pp. 269-93.

Christian, David. 2018. A History of Russia, Central Asia and Mongolia. Malden: Wiley-Blackwell, vol. 2.

Christodoulou, Georges, ed. 2009. Le Livre des Catéchèses de saint Néophyte le Reclus. Nicosie: Fondation de l'Archevêque Makarios III.

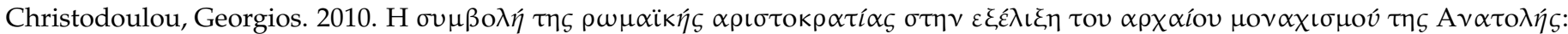

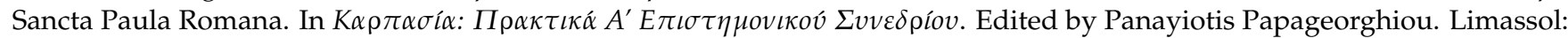
Free United Karpasia Association, pp. 93-108.

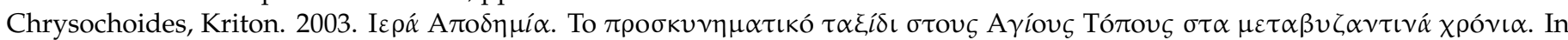

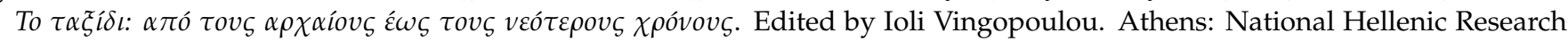
Foundation, pp. 99-110.

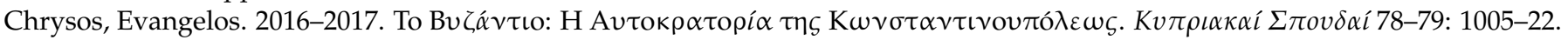

Costantakopoulou, Christy. 2007. The Dance of the Islands. Insularity, Networks, the Athenian Empire and the Aegean World. Oxford: Oxford University Press.

Costantini, Vera. 2009. Il sultano e l'isola Contesa. Cipro tra Eredità Veneziana e Potere Ottomano. Milan: UTET Libreria.

Coureas, Nicholas, Gilles Grivaud, and Chris Schabel. 2012. Frankish and Venetian Nicosia, 1191-1571. In Historic Nicosia. Edited by Demetrios Michaelides. Nicosia: Rimal, pp. 111-229.

Couroucli, Maria. 2014. Shared Sacred Places. In A Companion to Mediterranean History. Edited by Peregrine Horden and Sharon Kinoshita. Malden and Oxford: Wiley-Blackwell, pp. 378-91.

Creţu, Marianna-Stefania. 2015. Answer Given by Ms Creţu on Behalf of the Commission (Question Reference: E-008509/2014). European Parliament, Parliamentary Questions, January 7. Available online: https:/ /www.europarl.europa.eu/doceo/document/E8-2014-008509-ASW_EN.html (accessed on 2 June 2021).

Dafni, Amots. 2007a. Rituals, ceremonies and customs related to sacred trees with a special reference to the Middle East. Journal of Ethnobiology and Ethnomedicine 3: 1-15. [CrossRef]

Dafni, Amots. 2007b. The supernatural characters and powers of sacred trees in the Holy Land. Journal of Ethnobiology and Ethnomedicine 3: $1-16$. [CrossRef]

Dandelet, Thomas James. 2014. The Renaissance of Empire in Early Modern Europe. Cambridge: Cambridge University Press.

Dandini, Jerome. 1685. Voyage du Mont Liban, traduit de l'Italien. Paris: Louis Billaine [Bank of Cyprus Cultural Foundation, B-287]. First published 1675 .

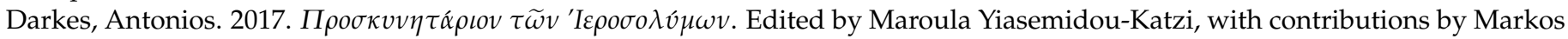
Foskolos and Nasa Patapiou. Limassol: Society of Kiolaniotes. First published 1645.

Della Dora, Veronica. 2016. Landscape, Nature, and the Sacred in Byzantium. Cambridge: Cambridge University Press.

Demesticha, Stella, Katerina Delouca, Mia Gaia Trentin, Nikolas Bakirtzis, and Andonis Neophytou. 2017. Seamen on Land? A Preliminary Analysis of Medieval Ship Graffiti on Cyprus. The International Journal of Nautical Archaeology 46: 346-81. [CrossRef]

Demilyürek, Mehmet. 2010. The Commercial Relations Between Venice and Cyprus After the Ottoman Conquest (1600-1800). Levant 42: $237-54$.

Department of Forests, Ministry of Agriculture, Natural Resources and Environment, Republic of Cyprus. 2012. Trees Nature Monuments of Cyprus. Available online: http:/ / www.moa.gov.cy/moa/fd/fd.nsf/F8684AD2DDA64365C22581290029A4E8 /\$file/Trees\%20Nature\%20Monuments\%20of\%20Cyprus\%20-\%20Four\%20fold\%20flyer.pdf (accessed on 2 June 2021).

Detoraki, Maria. 2014. Greek Passions of the Martyrs in Byzantium. In The Ashgate Research Companion to Byzantine Hagiography. Edited by Stephanos Efthymiadis. Farnham and Burlington: Ashgate, vol. 2, pp. 61-101.

Dever, William G. 2005. Did God Have a Wife? Archaeology and Folk Religion in Ancient Israel. Grand Rapids and Cambridge: Eerdmans.

Devos, Paul, ed. 1953. Le dossier hagiographique de S. Jacques l’Intercis (I). Analecta Bollandiana 71: 157-210. [CrossRef]

Devos, Paul, ed. 1954. Le dossier hagiographique de S. Jacques l'Intercis (II). Analecta Bollandiana 72: 213-56. [CrossRef]

Domingo, Plácido. 2019. Open Letter to the Two Leaders of Cyprus (25 February 2019). Europa Nostra. Available online: https:/ /www. europanostra.org/wp-content/uploads/2019/02/20190225-OpenLetter-PlacidoDomingo-CyprusLeaders-Nicosia.pdf (accessed on 2 June 2021).

Drakopoulou, Eugenia. 2013. In hoc Signo vinces between 1453-1571: The iconography of an encounter between art and history. НИШ ИВИЗАНТИЈА 12: 387-98.

Eade, John, and Dionigi Albera. 2017. Pilgrimage Studies in Global Perspective. In New Pathways in Pilgrimage Studies: Global Perspectives. Edited by Dionigi Albera and John Eade. New York and London: Routledge, pp. 1-17.

Eger, A. Asa. 2013. (Re)Mapping Medieval Antioch. Urban Transformations from the Early Islamic to the Middle Byzantine Periods. Dumbarton Oaks Papers 67: 95-134.

Eliades, Ioannis. 2017. Icons of Cyprus (1191-1300). In Maniera Cypria. The Cypriot Painting of the Thirteenth Century Between Two Worlds. Edited by Ioannis Eliades. Lefkosia: Archbishop Makarios III Foundation, pp. 80-107.

Ephrat, Daphna. 2021. Sufi Masters and the Creation of Holy Spheres in Medieval Syria. Leeds: Arc Humanities Press.

Eshel, Shay. 2018. The Concept of the Elect Nation in Byzantium. Leiden and Boston: Brill. 
Farahmand, Homayoun, and Harim R. Karimi. 2018. Old Persian cypress accessions, a rich and unique genetic resource for common cypress (Cupressus sempervirens L.) in the world. Acta Horticulturae 1190: 113-17. [CrossRef]

Febvre, Michel. 1682. Théâtre de la Turquie, Traduit d'Italien en François. Paris: Edme Couterot.

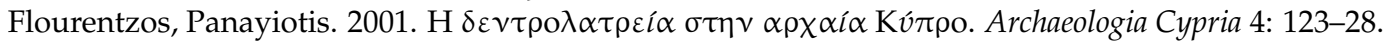

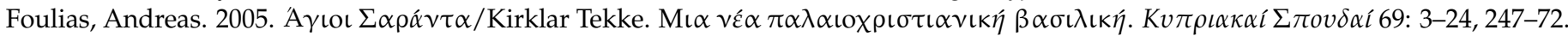

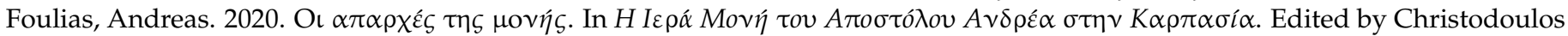
Hadjichristodoulou and Andreas Foulias. Nicosia: Holy Bishopric of Karpasia, pp. 71-104.

Franco, Laura. 2009. A Study of the Metaphrastic Process: The case of the unpublished Passio of St James the Persian (BHG 773), Passio of St Plato (BHG 1551-1552), and Vita of St Hilarion (BHG 755) by Symeon Metaphrastes. Ph.D. Thesis, Royal Holloway, University of London, London, UK.

Frazee, Charles A. 1983. Catholics and Sultans. The Church and the Ottoman Empire, 1453-1923. Cambridge: Cambridge University Press.

Frazer, James G. 1922. The Golden Bough: A Study in Magic and Religion, Abridged ed. New York: Macmillan.

Fumaroli, Marc. 1995. Cross, Crown, and Tiara: The Constantine Myth between Paris and Rome (1590-1690). Studies in the History of Art 48: 88-102.

Galadza, Daniel. 2018. Liturgy and Byzantinization in Jerusalem. Oxford: Oxford University Press.

Gonzalez, Delfin. 1991. Snakebite Problems in Europe. In Handbook of Natural Toxins. Edited by Anthony T. Tu. New York: Marcel Dekker, vol. 5, pp. 687-754.

Goodison, Lucy. 2016. Holy Trees and Other Ecological Surprises. Dorset: Just Press.

Grehan, James. 2014. Twilight of the Saints: Everyday Religion in Ottoman Syria and Palestine. Oxford: Oxford University Press.

Grierson, Roderick. 2014. "One Shrine Alone": Christians, Sufis, and the Vision of Mawlana. In The Philosophy of Ecstasy. Rumi and the Sufi Tradition. Edited by Leonard Lewisohn. Bloomington: World Wisdom, pp. 83-126.

Grivaud, Gilles. 1995. Éveil de la nation chyproise (XII $-X V^{\mathrm{e}}$ siècles). Sources Travaux Historiques 43-44: 105-16.

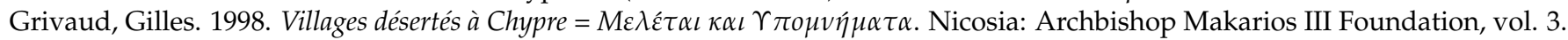

Hadjianastasis, Marios. 2009. Cyprus in the Ottoman Period: Consolidation of the Cypro-Ottoman Elite, 1650-1750. In Ottoman Cyprus: A Collection of Studies on History and Culture. Edited by Michalis N. Michael, Matthias Kappler and Eftihios Gavriel. Wiesbaden: Harrassowitz Verlag, pp. 63-88.

Hadjikyriacou, Antonis. 2016. The Ottomanisation of Cyprus: Towards a spatial imagination beyond the centre-province binary. Journal of Mediterranean Studies 25: 81-96.

Hadjikyriacou, Antonis. 2017. Envisioning Insularity in the Ottoman World. Princeton Papers: Interdisciplinary Journal of Middle Eastern Studies, 18.

Hadjikyriacou, Antonis. 2019a. Akdeniz Çerçevesi Içinde Osmanli Kibris'inda Tahil Üretimi. Meltem 6: 6-30. [CrossRef]

Hadjikyriacou, Antonis. 2019b. Beyond the millet debate: Communal representation in pre-Tanzimat-era Cyprus. In Political thought and Practice in the Ottoman Empire. Halcyon Days in Crete IX. Edited by Marinos Sariyannis. Rethymno: Crete University Press, pp. 71-96.

Håland, Evy Johanne. 2011. Saints and Snakes: Death, Fertility, and Healing in Modern Ancient Greece and Italy. Performance and Spirituality 2: 111-51.

Harmansah, Rabia. 2021. "Fraternal" Other: Negotiating Ethnic and Religious Identities at a Muslim Sacred Site in Northern Cyprus. Nationalities Papers 1-19. [CrossRef]

Harris, William. 2012. Lebanon: A History, 600-2011. Oxford: Oxford University Press.

Hasluck, Frederick W. 1929. Christianity and Islam under the Sultans. Oxford: Clarendon Press, vol. 1.

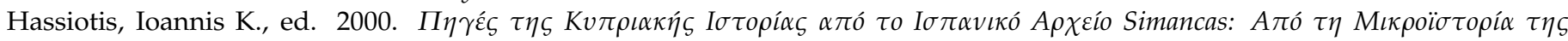

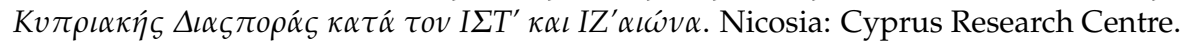

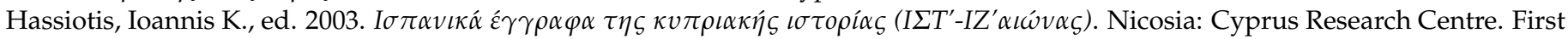
published 1972.

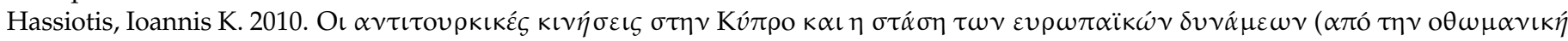

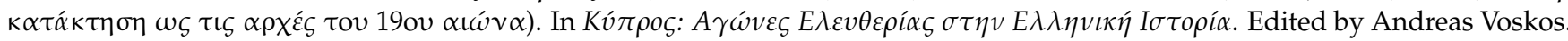
Athens: National and Kapodistrian University of Athens, pp. 147-87.

Hatay, Mete. 2015. "Reluctant" Muslims? Turkish Cypriots, Islam, and Sufism. The Cyprus Review 27: 43-63.

Hayden, Robert M. 2013. Intersecting Religioscapes and Antagonistic Tolerance: Trajectories of Competition and Sharing of Religious Spaces in the Balkans. Space and Polity 17: 320-34. [CrossRef]

Hayden, Robert M., Tugba Tanyeri-Erdemir, Timothy D. Walker, Aykan Erdemir, Devika Rangachari, Manuel Aguilar-Moreno, Enrique López-Hurtado, and Milika Bakic-Hayden. 2016. Antagonistic Tolerance. Competitive Sharing of Religious Sites and Spaces. London and New York: Routledge.

Heyberger, Bernard. 2012. Polemic Dialogues between Christians and Muslims in the Seventeenth Century. Journal of Economic and Social History of the Orient 55: 495-516. [CrossRef]

Heyden, Katharina. 2020. Construction, Performance, and Interpretation of a Shared Holy Place. The Case of Late Antique Mamre (Rāmat al-Khalīl). Entangled Religions 11: 1-29. [CrossRef]

Horden, Peregrine, and Nicholas Purcell. 2006. The Mediterranean and "the New Thalassology". The American Historical Review 111: 722-40. [CrossRef] 
Hovorun, Serhiy. 2003. Theological Controversy in the Seventh Century Concerning Activities and Wills in Christ. Ph.D. Thesis, University of Durham, Durham, UK.

Hunt, Alisa. 2016. Reviving Roman Religion: Sacred Trees in the Roman World. Cambridge: Cambridge University Press.

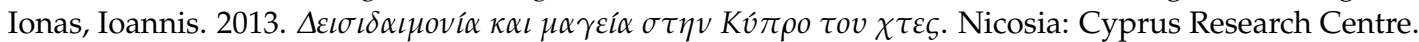

Izmirlieva, Valentina. 2014. Christian Hajjis-The Other Orthodox Pilgrims to Jerusalem. Slavic Review 73: 322-46. [CrossRef]

Jacoby, David. 2016. Evolving routes of Western pilgrimage to the Holy Land, eleventh to fifteenth century: An overview. In Unterwegs im Namen der Religion II/On the Road in the Name of Religion II. Edited by Klaus Herbers and Hans Christian Lehner. Stuttgart: Franz Steiner, pp. 75-97.

Jennings, Ronald C. 1988. The Locust Problem in Cyprus. Bulletin of the School of Oriental and African Studies 51: 279-313. [CrossRef]

Jennings, Ronald C. 1993. Christians and Muslims in Ottoman Cyprus and the Mediterranean World, 1571-1640. New York and London: New York University Press.

Jestrzemski, Daniel, and Irina Kuzyakova. 2018. Morphometric characteristics and seasonal proximity to water of the Cypriot blunt-nosed viper Macrovipera lebetina lebetina (Linnaeus, 1758). Journal of Venomous Animals and Toxins including Tropical Diseases 24: 1-18. [CrossRef]

Kaffenberger, Thomas. 2020. Tradition and Identity. The Architecture of Greek Churches in Cyprus (14th to 16th Centuries). Wiesbaden: Reichert Verlag.

Kaldellis, Anthony. 2019a. Byzantium Unbound. Leeds: Arc Humanities Press.

Kaldellis, Anthony. 2019b. Romanland: Ethnicity and Empire in Byzantium. Cambridge and London: Harvard University Press.

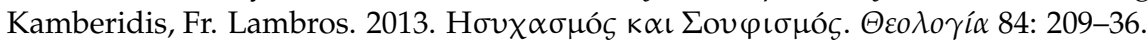

Kaplanis, Tassos A. 2014. Antique Names and Self-Identification: Hellenes, Graikoi, and Romaioi from Late Byzantium to the Greek Nation-State. In Re-imagining the Past. Antiquity and Modern Greek Culture. Edited by Dimitris Tziovas. Oxford: Oxford University Press, pp. 81-96.

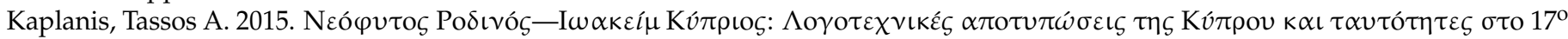

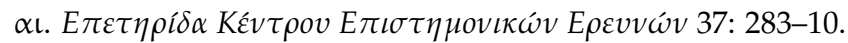

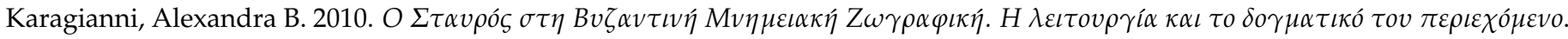
Thessaloniki: Byzantine Research Centre.

Kitromilides, Paschalis M. 2009. F. W. Hasluck and Christianity and Islam under the Sultans. In Scholars, Travels, Archives: Greek History and Culture through the British School at Athens. Edited by Michael Lewellyn Smith, Paschalis Kitromilides and Eleni Calligas. London: British School at Athens, pp. 103-9.

Kitto, John. 1840. The Illustrated Commentary on the Old and New Testaments, Chiefly Explanatory of the Manners and Customs Mentioned in the Sacred Scriptures; and also of History, Geography, Natural History, and Antiquities; Being a Republication of the Notes of the Pictorial Bible of a Size Which Will Range with the Authorized Editions of the Sacred Text. London: Charles Knight \& Co., vol. 3.

Knapp, Arthur Bernard. 2007. Insularity and island identity in the prehistoric Mediterranean. In Mediterranean Crossroads. Edited by Sophia Antoniadou and Anthony Price. Athens: Pierides Foundation, pp. 37-62.

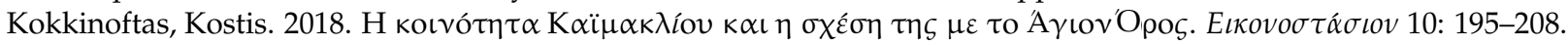

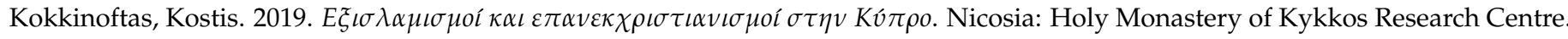

Kolovos, Elias, and Phokion Kotzageorgis. 2019. Searching for the "Little Ice Age" effects in the Ottoman Greek lands: The cases of Salonica and Crete. In Seeds of Power: Explorations in Ottoman Environmental History. Edited by Onur Inal and Yavuz Köse. Winwick: The White Horse Press, pp. 17-34.

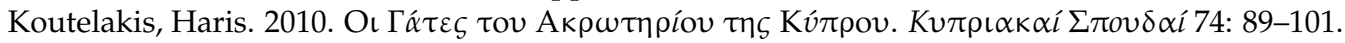

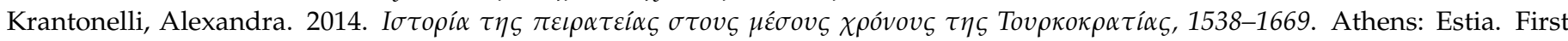
published 1991.

Krstić, Tijana. 2021. Historicizing the Study of Sunni Islam in the Ottoman Empire, c. 1450-c. 1750. In Historicizing Sunni Islam in the Ottoman Empire, c. 1450-c. 1750. Edited by Tijana Krstić and Derin Terzioğlu. Leiden and Boston: Brill, pp. 1-27.

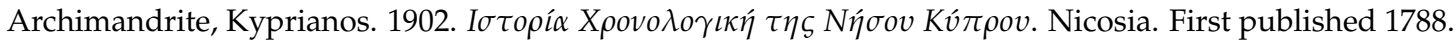

Kyriacou, Chrysovalantis. 2018. Orthodox Cyprus under the Latins: Society, Spirituality, and Identities, 1191-1571. New York and London: Lexington Books.

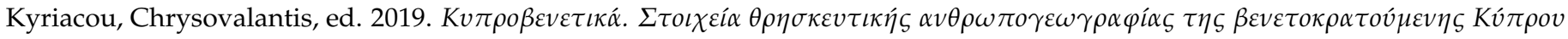

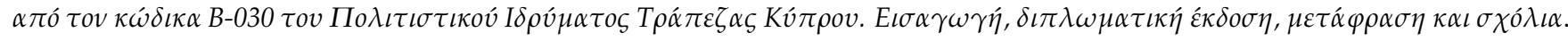
Nicosia: Holy Monastery of Kykkos Museum.

Kyriacou, Chrysovalantis. 2020a. Christian Diversity in Late Venetian Cyprus. A Study and English Translation of Codex B-030 from the Collections of the Bank of Cyprus Cultural Foundation. Lefkosia: Bank of Cyprus Cultural Foundation.

Kyriacou, Chrysovalantis. 2020b. The Byzantine Warrior Hero: Cypriot Folk Songs as History and Myth, 965-1571. New York and London: Lexington Books.

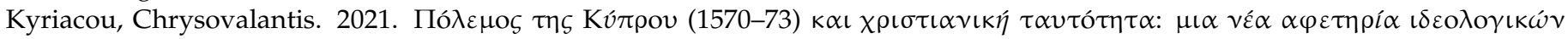

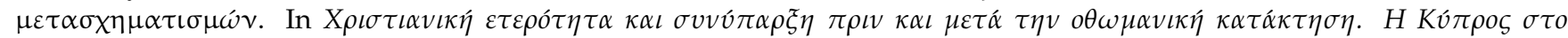

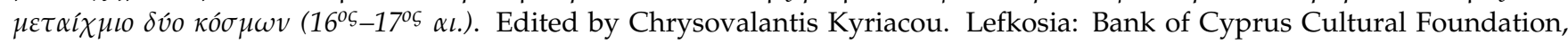
pp. 1-32.

Kyrris, Costas P., ed. 1987. The Kanakaria Documents, 1666-1850: Sale and Donation Deeds. Nicosia: Cyprus Research Centre. 


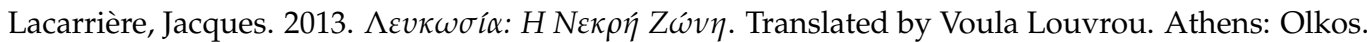

Le Goff, Jacques. 2015. Must We Divide History into Periods? Translated by Malcolm B. DeBevoise. New York: Columbia University Press.

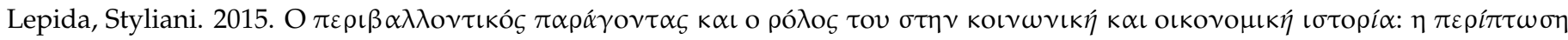

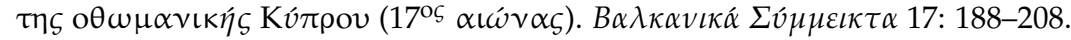

Lidov, Alexei, ed. 2009. Hierotopy. The Creation of Sacred Spaces as a Form of Creativity and Subject of Cultural History. In Hierotopy. Spatial Icons and Image-Paradigms in Byzantine Culture. Moscow: Design. Information. Cartography, pp. 32-58.

Lightbody, David Ian. 2011. Signs of conciliation: The hybridised "Tree of Life" in the Iron Age City Kingdoms of Cyprus. Cahiers du Centre d'Études Chypriotes 41: 239-50. [CrossRef]

Lissovsky, Nurit. 2012. Sacred Trees-Holy Land. Studies in the History of Gardens \& Designed Landscapes: An International Quarterly 24: 65-89.

Loukatos, Demetrios S. 1962. Aкоv Athanasios Martinos, vol. 1, pp. 1224-25.

Lounghis, Telemachos C. 2010. Byzantium in the Eastern Mediterranean: Safeguarding East Roman Identity. Nicosia: Cyprus Research Centre.

Luig, Ute, ed. 2018. Approaching the Sacred. Pilgrimage in Historical and Intercultural Perspective. In Approaching the Sacred. Pilgrimage in Historical and Intercultural Perspective. Berlin: Topoi, pp. 7-36.

Lusignan, Estienne de. 1580. Description de toute l'isle de Cypre. Paris: Guillaume Chaudiere.

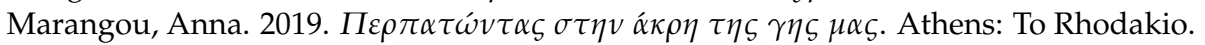

Marchesano, Louis. 2010. Charles Le Brun's Constantine Prints for Louis XIV and Jean-Baptiste Colbert. In L'estampe au Grand Siècle. Études offertes à Maxime Préaud. Edited by Peter Fuhring, Barbara Brejon de Lavergnée, Marianne Grivel, Séverine Lepale and Véronique Meyer. Paris: École nationale des chartes/Bibliothèque nationale de France, pp. 463-83.

Mariti, Giovanni. 1792. Travels through Cyprus, Syria and Palestine: With a General History of the Levant. Translated from the Italian. Charlestown: Pranava Books, vol. 1.

Mavrojannis, Theodoros. 2015. Roman Temples of Kourion and Amathus in Cyprus: A Chapter in the Arabian Policy of Trajan. In Literature, Scholarship, Philosophy and History. Classical Studies in Memory of Ioannis Taifacos. Edited by Georgios A. Xenis. Stuttgart: Franz Steiner, pp. 457-502.

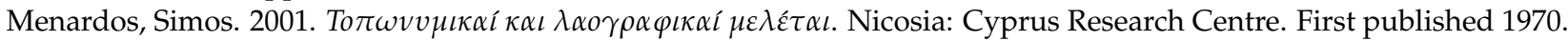

Metcalf, David M. 2009. Byzantine Cyprus, 491-1191. Nicosia: Cyprus Research Centre.

Michael, Maria. 2015. Ship graffiti in context: A preliminary study of Cypriot patterns. In Cypriot Cultural Details. Proceedings of the 10th Post Graduate Cypriot Archaeology Conference. Edited by Iosif Hadjikyriakos and Mia Gaia Trentin. Oxford and Philadelphia: Oxbow Books, pp. 41-64.

Miklosich, Francis, and Joseph Müller, eds. 1865. Acta et Diplomata Graeca Medii Aevi. Vienna: C. Gerold, vol. 3.

Miller, F. Justus, ed. 1916. Ovid, Metamorphoses. London: Harvard University Press, vol. 2.

Mlynarczyk, Jolanta. 1980. The Paphian Sanctuary of Apollo Hylates. In Report of the Department of Antiquities Cyprus. Cyprus: Department of Antiquities, pp. 239-52.

Naaman, Abbot Paul. 2011. The Maronites: The Origins of an Antiochene Church. A Historical and Geographical Study of the Fifth to Seventh Centuries. Translated by the Department of Interpretation and Translation, Holy Spirit University. Trappist: Cistercian Publications.

Nicolaou-Konnari, Angel. 2000-2001. Ethnic names and the construction of group identity in medieval and early modern Cyprus: The

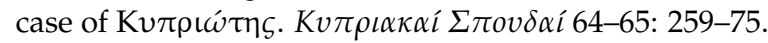

Nicolaou-Konnari, Angel, and Chris Schabel. 2015. Limassol under Latin rule, 1191-1571. In Lemesos. A History of Limassol in Cyprus from Antiquity to the Ottoman Conquest. Edited by Angel Nicolaou-Konnari and Chris Schabel. Newcastle upon Tyne: Cambridge Scholars Publishing, pp. 195-361.

Noonan, F. Thomas. 2007. The Road to Jerusalem. Pilgrimage and Travel in the Age of Discovery. Philadelphia: University of Pennsylvania Press.

O'Connell, Monique. 2017. Venice: City of merchants or city for merchandise? In The Routledge Handbook of Maritime Trade Around Europe, 1300-1600. Edited by Wim Blockmans, Mikhail Krom and Justyna Wubs-Mrozewicz. London and New York: Routledge, pp. 103-20.

Oancea, Constantin. 2017. Chaoskampf in the Orthodox Baptism Ritual. Acta Theologica 37: 125-42. [CrossRef]

Ogden, Daniel. 2013. Drakon: Dragon Myth and Serpent Cult in the Greek and Roman Worlds. Oxford: Oxford University Press.

Ohnefalsch-Richter, Magda H. 2006. Greek Customs and Mores in Cyprus, with Comments on Natural History and the Economy and Progress under British Rule. Translated by Vassilis D. Angelis. Nicosia: Laiki Group Cultural Centre. First published 1913.

Olympios, Michalis. 2013. Shared Devotions: Non-Latin Responses to Latin Sainthood in Late Medieval Cyprus. Journal of Medieval History 39: 321-41. [CrossRef]

Olympios, Michalis. 2015. Rummaging through ruins: Architecture in Limassol in the Lusignan and Venetian periods. In Lemesos. A History of Limassol in Cyprus from Antiquity to the Ottoman Conquest. Edited by Angel Nicolaou-Konnari and Chris Schabel. Newcastle upon Tyne: Cambridge Scholars Publishing, pp. 362-500. 
Pamuk, Şevket. 2001. The Price Revolution in the Ottoman Empire Reconsidered. International Journal of Middle East Studies 33: 69-89. [CrossRef]

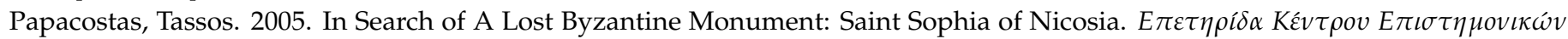

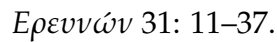

Papacostas, Tassos. 2012. Byzantine Nicosia, 650-1191. In Historic Nicosia. Edited by Demetrios Michaelides. Nicosia: Rimal, pp. 77-109.

Papacostas, Tassos. 2015. Neapolis/Nemesos/Limassol: The rise of a Byzantine settlement from Late Antiquity to the time of the Crusades. In Lemesos. A History of Limassol in Cyprus from Antiquity to the Ottoman Conquest. Edited by Angel Nicolaou-Konnari and Chris Schabel. Newcastle upon Tyne: Cambridge Scholars Publishing, pp. 96-188.

Papacostas, Tassos, Cyril Mango, and Michael Grünbart. 2007. The History and Architecture of the Monastery of Saint John Chrysostomos at Koutsovendis, Cyprus. Dumbarton Oaks Papers 61: 25-156.

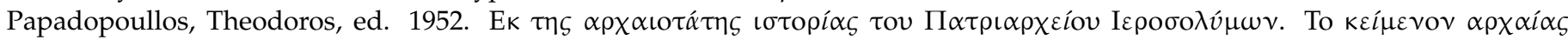

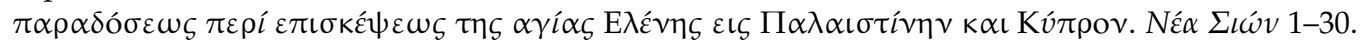

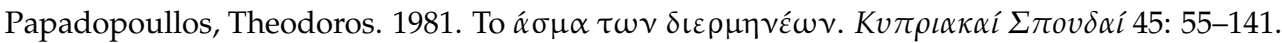

Papageorghiou, Athanasios. 1976. Byzantine Icons from Cyprus (Benaki Museum). Translated by Kay Tsitselis. Athens: Benaki Museum.

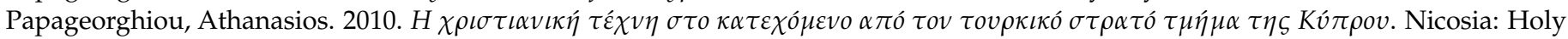
Archbishopric of Cyprus.

Papantoniou, Giorgos. 2012. Religion and Social Transformations in Cyprus: From the Cypriot Basileis to the Hellenistic Strategos. Leiden and Boston: Brill.

Papantoniou, Giorgos. 2016. Cypriot ritual and cult from the Bronze to the Iron Age: A longue-durée approach. Journal of Greek Archaeology 1: 73-108.

Patapiou, Nasa. 2009. Larnaka during Venetian rule from unpublished documents in the State Archive of Venice. Cyprus Today, 15-27.

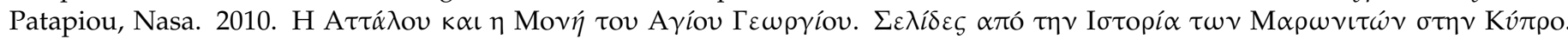

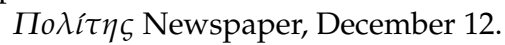

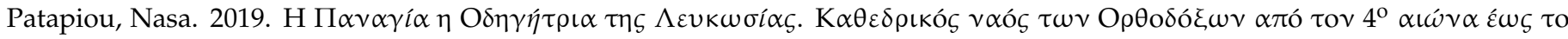

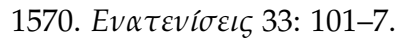

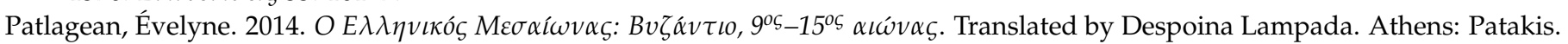

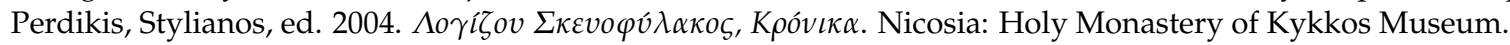

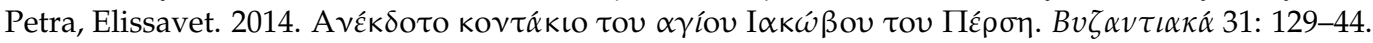

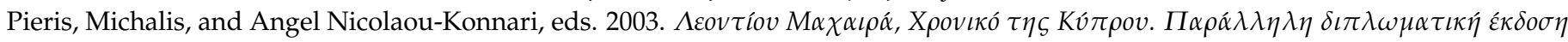

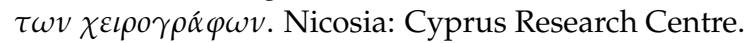

Pilides, Despina. 2012. A short account of the recent discoveries made on the hill of Ayios Yeorgios (PASYDY). In Historic Nicosia. Edited by Demetrios Michaelides. Nicosia: Rimal, pp. 212-14.

Psychogiou, Eleni. 2008. "M $\mu о \iota \rho \lambda o ́ \gamma \iota \alpha \sigma \tau \eta \sigma \hat{v} \gamma \chi \rho o v \eta E \lambda \lambda \alpha ́ \delta \alpha$. Athens: Academy of Athens.

Richard, Jean, ed. 1981. Une famille de 'Vénitiens blancs' dans le royaume de Chypre au milieu du XVe siècle: Les Audet et la seigneurie du Marethasse. Rivista di Studi Bizantini e Slavi 1: 89-129.

Richard, Jean, and Théodore Papadopoullos, eds. 1983. Le livre des remembrances de la secrète du Royaume de Chypre (1486-1469). Nicosie: Centre de Recherches Scientifiques.

Rigsby, Kent J. 1996. Missing Places. Classical Philology 91: 254-60. [CrossRef]

Rizopoulou-Egoumenidou, Euphrosyne. 2012. Nicosia under Ottoman Rule, 1570-1878, Part II. In Historic Nicosia. Edited by Demetrios Michaelides. Nicosia: Rimal, pp. 265-322.

Römer, Claudia. 2001. The sea in comparisons and metaphors in Ottoman historiography in the sixteenth century. Oriente Moderno, Nuova Serie 20: 233-44. [CrossRef]

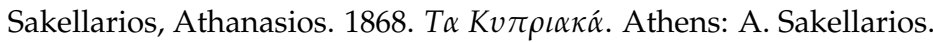

Salibi, Kamal S. 1959. Maronite Historians of Mediaeval Lebanon. Beirut: American University of Beirut.

Salvator, Louis. 1881. Levkosia, the Capital of Cyprus. Translated by the Chevalier de Krapf Liverhoff. London: C. Kegan Paul \& Co.

Translated and Edited by Christopher Schabel. 2001, The Synodicum Nicosiense and Other Documents of the Latin Church of Cyprus, 1196-1373. Nicosia: Cyprus Research Centre.

Scranton, Robert. 1967. The Architecture of the Sanctuary of Apollo Hylates at Kourion. Transactions of the American Philosophical Society 57: 3-85. [CrossRef]

Seggiano, Ignazio da. 1962. L'opera dei Cappuccini per l'unione dei Cristiani nel Vicino Oriente Durante il Secolo XVII. Roma: Institutum Orientalium Studiorum.

Simsky, Andrew. 2020. The Discovery of Hierotopy. Journal of Visual Theology 1: 9-28.

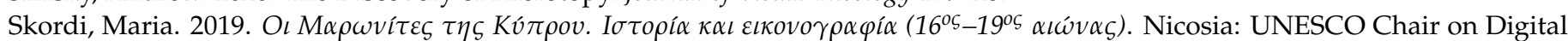
Cultural Heritage, Cyprus University of Technology.

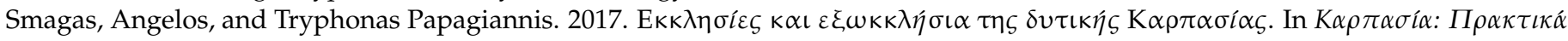

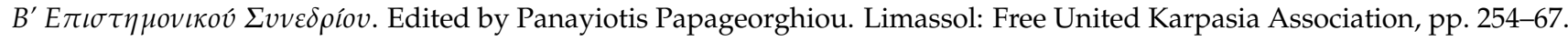

Smith, Kyle. 2016. Constantine and the Captive Christians of Persia. Martyrdom and Religious Identity in Late Antiquity. Oakland: University of California Press. 
Snelders, Bas, and Mat Immerzeel. 2012-2013. From Cyprus to Syria and Back Again: Artistic Interaction in the Medieval Levant. Eastern Christian Art 9: 79-106.

Sophocleous, Sophocles. 2014. Cypriot Icons Before the Twelfth Century. In Cyprus and the Balance of Empires. Art and Archaeology from Justinian I to the Coeur de Lion. Edited by Charles Anthony Stewart, Thomas W. Davis and Annemarie Weyl Carr. Boston: American Schools of Oriental Research, pp. 135-51.

Soren, David, ed. 1987. The Sanctuary of Apollo Hylates at Kourion, Cyprus. Tuscon: The University of Arizona Press.

Stephenson, Paul. 2016. The Serpent Column: A Cultural Biography. Oxford: Oxford University Press.

Stouraitis, Yannis. 2017. Reinventing Roman Ethnicity in High and Late Medieval Byzantium. Medieval Worlds: Comparative E Interdisciplinary Studies 5: 70-94.

Stylianou, Andreas, and Judith A. Stylianou. 1985. The Painted Churches of Cyprus. Treasures of the Byzantine Art. London: A. G. Leventis Foundation.

Tabak, Faruk. 2008. The Waning of the Mediterranean, 1550-1870: A Geohistorical Approach. Baltimore: The Johns Hopkins University Press.

Taft, Robert F. 1992. The Byzantine Rite: A Short History. Collegeville: The Liturgical Press.

Tannous, Jack. 2018. The Making of the Medieval Middle East. Religion, Society, and Simple Believers. Princeton and Oxford: Princeton University Press.

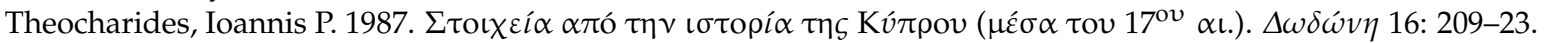

Theodoropoulos, Panagiotis. 2021. Did the Byzantines call themselves Byzantines? Elements of Eastern Roman identity in the imperial discourse of the seventh century. Byzantine and Modern Greek Studies 45: 25-41. [CrossRef]

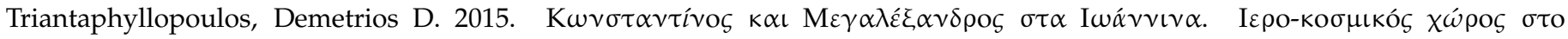

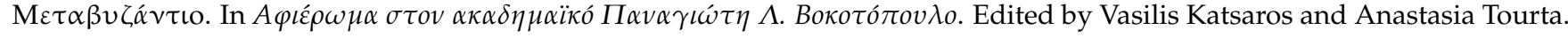
Athens: Kapon, pp. 527-38.

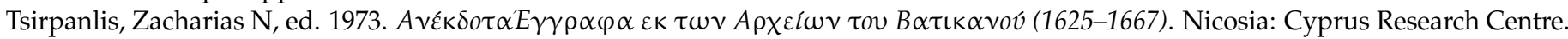

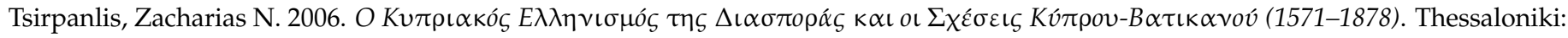
Ant. Stamoulis.

Tsumura, David T. 2005. Creation and Destruction. A Reappraisal of the Chaoskampf Theory in the Old Testament. Winona Lake: Eisenbrauns. Tully, Caroline Jane. 2018. Cultic Life of Trees in the Prehistoric Aegean, Levant, Egypt and Cyprus. Leuven: Peeters.

Turner, Harold W. 1979. From Temple to the Meeting House: The Phenomenology and Theology of Places of Worship. The Hague: Mouton.

Turner, Victor, and Edith Turner. 1978. Image and Pilgrimage in Christian Culture. Anthropological Perspectives. New York: Columbia University Press.

Villamont, Jacques de. 1609. Les Voyages du Seigneur de Villamont. Paris: Claude Lariot [Bank of Cyprus Cultural Foundation, B-166]. First published 1596.

Vionis, Athanasios K., and Giorgos Papantoniou. 2019. Central Place Theory Reloaded and Revised: Political Economy and Landscape Dynamics in the Longue Durée. Land 8: 36. [CrossRef]

Walsh, Michael J. K. 2006. Martyrs and Mariners: Some Surviving Art in the Church of Saints Peter and Paul, Famagusta, Cyprus. Mediterranean Studies 15: 21-41.

Walsh, Michael J. K. 2007. "On of the Princypalle Havenes of the See": The Port of Famagusta and the Ship Graffiti in the Church of St George of the Greeks, Cyprus. The International Journal of Nautical Archaeology 37: 1-15. [CrossRef]

Walter, Christopher. 2006. The Iconography of Constantine the Great, Emperor and Saint (with Associated Studies). Leiden: Alexandros Press.

Wartburg, Marie-Louise von, and Yiannis Violaris. 2009. Pottery of a 12th-Century Pit from the Palaion Demarcheion Site in Nicosia: A Typological and Analytical Approach to a Closed Assemblage. In Actas del VIII Congreso Internacional de Cerámica Medieval en el Mediterráneo. Edited by Juan Zozaya, Manuel Retuerce, Miguel Ángel Hervás and Antonio de Juan. Ciudad Real: Asociación Espanõla de Arqueología Medieval, vol. 1, pp. 249-64.

White, Sam. 2011. The Climate of Rebellion in the Early Modern Ottoman Empire. Cambridge: Cambridge University Press.

Xoplaki, Elena, Jürg Luterbacher, Sebastian Wagner, Eduardo Zorita, Dominik Fleitmann, Johannes Preiser-Kapeller, Abigail M. Sargent, Sam White, Andrea Toreti, John F. Haldon, and et al. 2018. Modelling Climate and Societal Resilience in the Eastern Mediterranean in the Last Millenium. Human Ecology 46: 363-79. [CrossRef]

Young, Robert J. C. 1995. Colonial Desire: Hybridity in Theory, Culture and Race. London and New York: Routledge.

Young, Philip H. 2005. The Cypriot Aphrodite Cult: Paphos, Rantidi, and Saint Barnabas. Journal of Near Eastern Studies 64: 23-44. [CrossRef] 